\title{
المماية الجنائية للبيئة البرية فى القانون المقارن
}

\section{خديجة هجاهدى"}

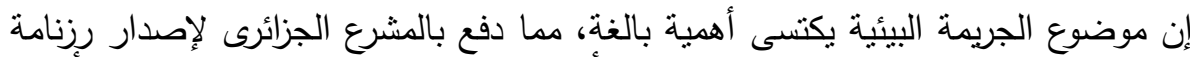

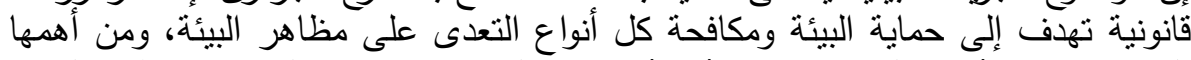

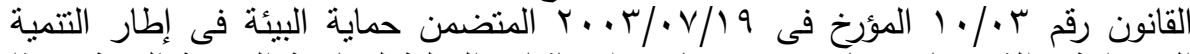

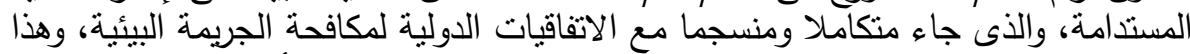

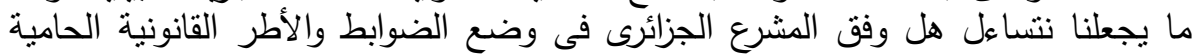

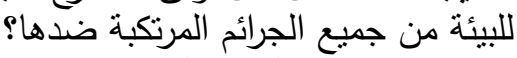

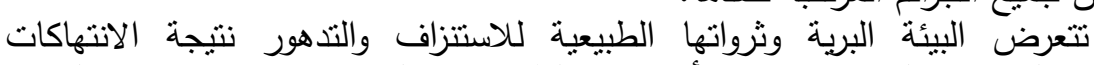

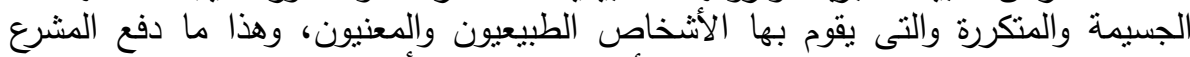

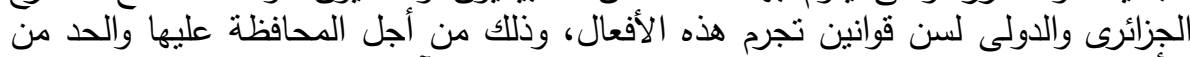

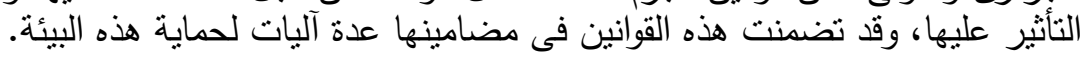

\section{مقدهـة}

إذا كانت تعرف البيئة البرية على أنها ذلك الوسط الطبيعى الذى يعيش فيه الإنسان، فإن مصطلح البيئة البرية يقصد به الوسط الطبيعى أو المجال البهال

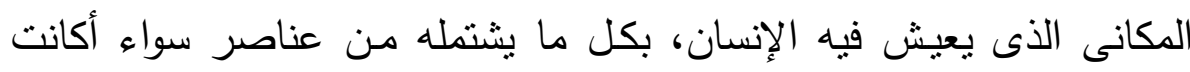

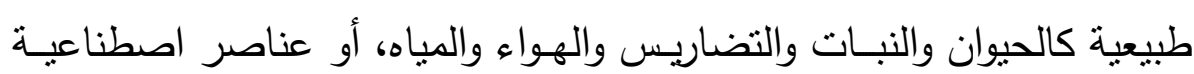
كانت من صنع يد الإنسان كالعمران والطرق والمصانع والسدود والقرى والمدن.

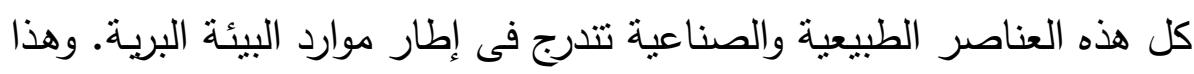

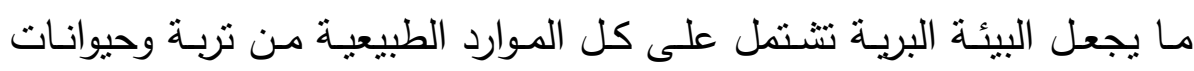

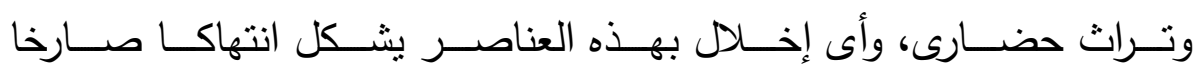

* أستاذ مساعد، كلية الحقوق والعلوم السياسية، جامعة البليدة، الجزائر . المجلة الجنائية القومية، المجلد الثانى والستون، العدد الأول، ماسس 9 . . . . 
للبيئة البرية، ويعتبر الغطاء النباتى للبيئة البرية، والحيوانات البرية، والتربة، والبيئة الحضرية، والتراث الثقافى هى المصدر الأساسى للبيئة البرية.

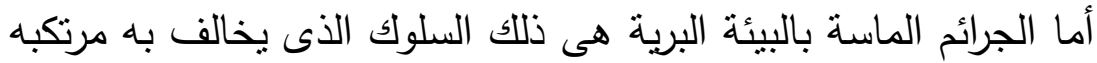

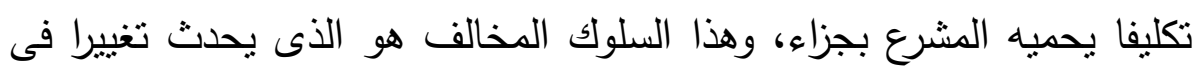

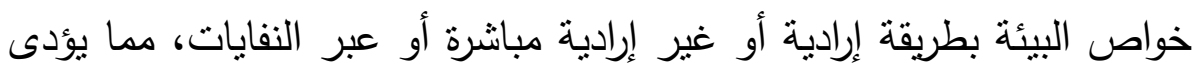

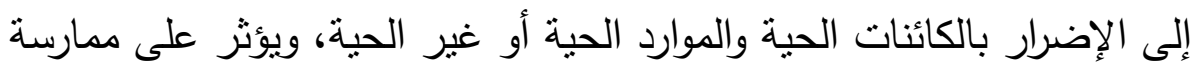

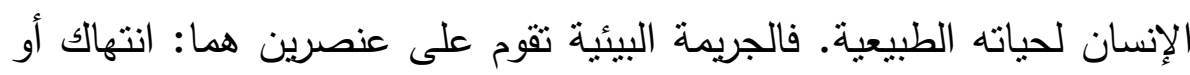

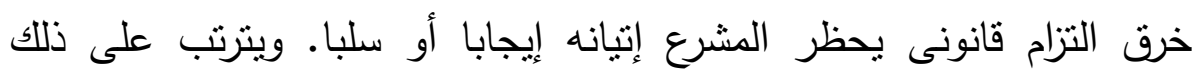
حدوث نتيجة ضارة بالبيئة، يترتب القانون على حدوثها جزاء جنائيا. إن من خصائص الحماية الجنائية لموارد البيئة البرية هو حماية الإنسان من كل ما يمس بصحته وأمنه العام، ولهذا أجمعت التشريعات المقارنة على الئه ردع كثير من المخالفات التى تشكل انتهاكا صارخا للبيئة البرية ومنها: تجريم

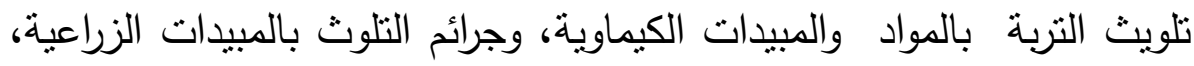
وتلويث التربة بمواد البناء، وجرائم تلويت البيئة بالنفايات أيا كانت طبيعتها، كما

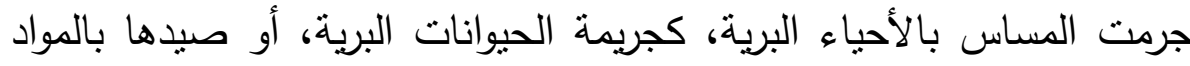

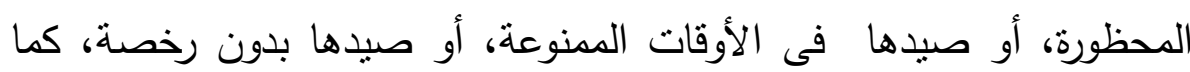

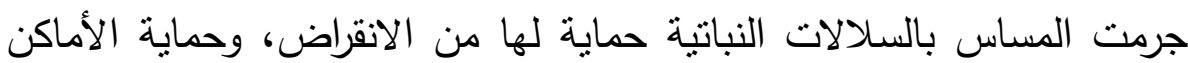
المحمية وكل ما يوجد فيها حيوانات ونباتات.

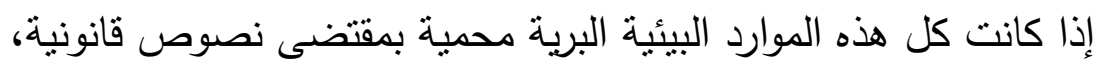

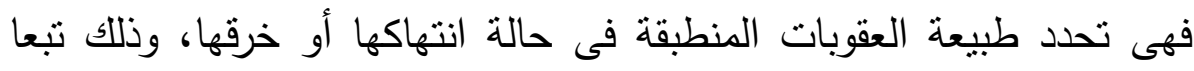

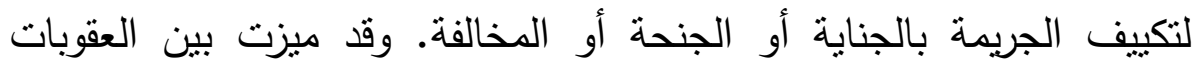
الأصلية والعقوبات التكميلية. 
كما حددت طبيعة القواعد الإجرائية التى تحكم متابعة وملاحقة مرتكبى جرائم البيئة البرية، كما بيّنت دور أجهزة الضبط الإدارى فى حماية البيئة البرية، وتحديد مهام كل جهة إدارية فى حماية البيئة البرية. أما إثكالية البحث نحصرها فى التساؤلات التالية: ما مدى تأثير جرائم

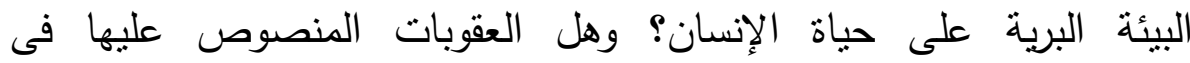
التثريعات الوطنية المقارنة كفيلة بالحد من انتهاك وخرق للموارد البيئية البرية؟ ومدى انسجام وتتاسق مهام الجهات الإدارية المكلفة بالعناية بالبيئة البرية

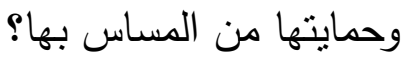

\section{أولاً: هاهية جرائم البيئة البرية}

يعد موضوع حماية البيئة والمحافظة عليها من اهتمامات الاتفاقيات الدولية والنتريعات الدقارنة، لأن الحديث عن حماية البيئة هو حديث عن سلامة الئه

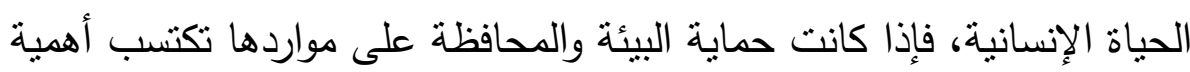
خاصة فى وقت السلم، فإن حمايتها فى زمن الحروب يكتسب أهمية كبرى، إنها

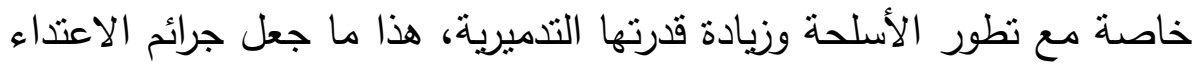
على البيئة الطبيعية إحدى صور الجرائم الدولية المنصوص عليها فى النظام

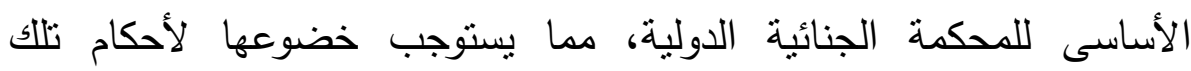

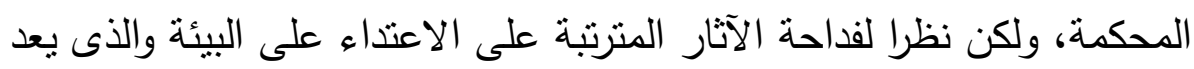
اعتداء على الإنسان ذاته بتدمير سبل ومقومات حياته فى هذا الكون.

ا - هفهوم البيئة البرية فقها وقانونا من أجل توضيح مفهوم البيئة البرية، يستوجب تعريفها من الناحية الفقهية والقانونية. 


\section{- التعريف الفقهى البيئة البرية}

تعرف البيئة إيكولوجيا على أنها: "مجموع المؤشرات والظروف الخارجية

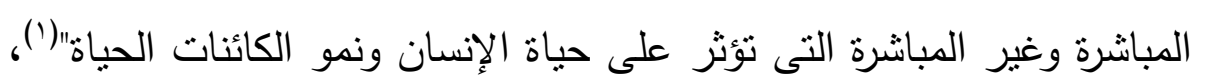

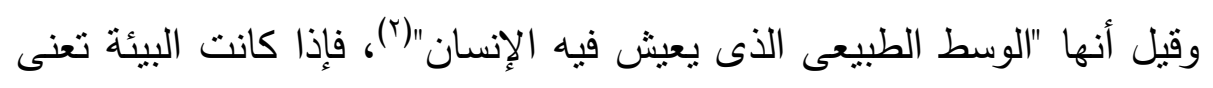
كل ما يحيط بالإنسان من ظروف خارجية تؤثثر فيه ويتأثر بها، فالبيئة البرية

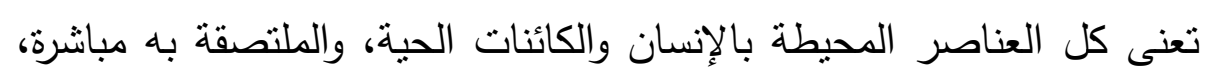
وما تشمله من حيوانات ونباتات يؤثر فيها ويتأثر بها.

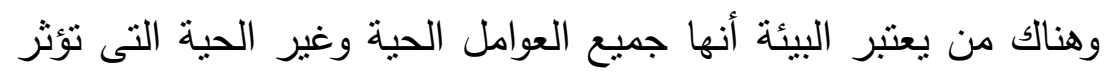

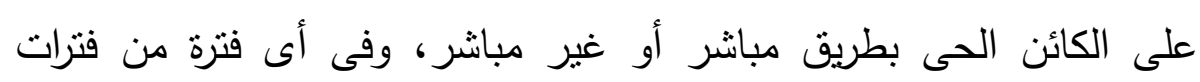

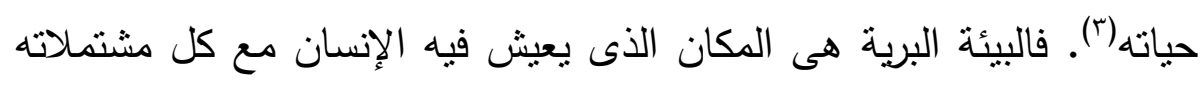
الطبيعية من حيوان ونبات وتضاريس وهواء ومياه، ومشتملاته الصناعية

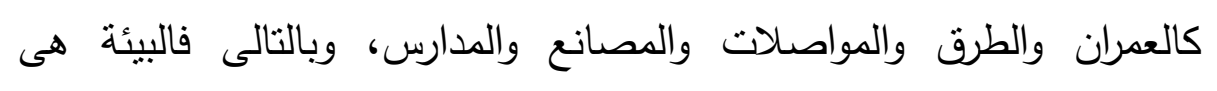

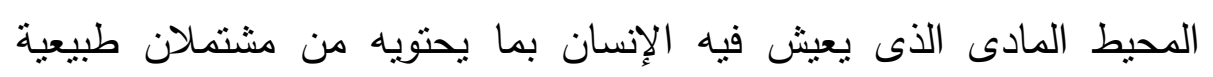
وصناعية.

وقد عرف المشرع الفرنسى البيئة بأنها "فضاء الموارد والوسط الطبيعى

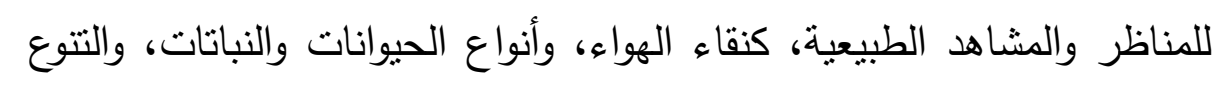

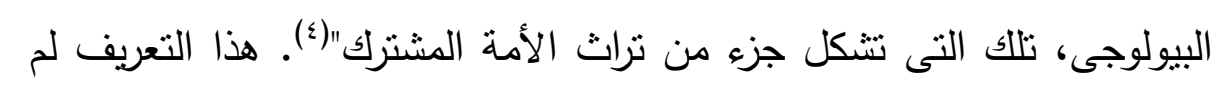

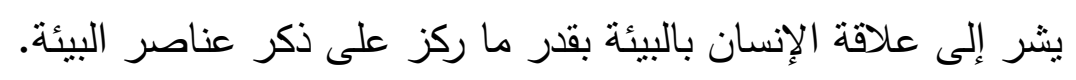

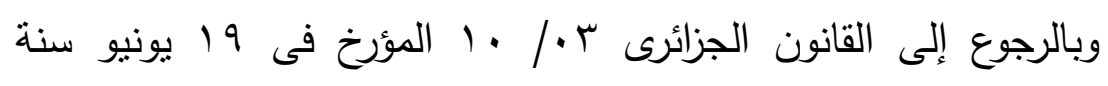

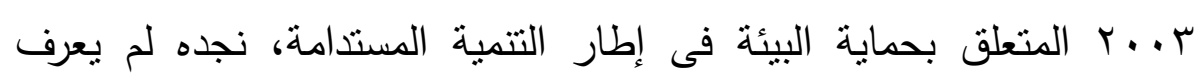

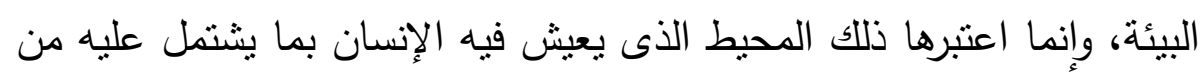

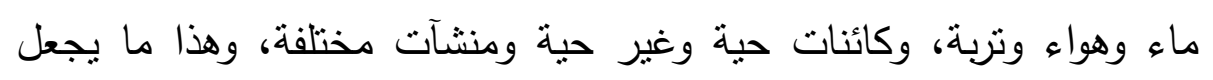


البيئة تثتمل على عناصر طبيعية وأخرى اصطناعية. فالعناصر الطبيعية هى

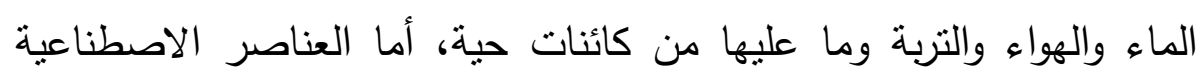
فهى ما أوجده الإنسان من مرافق ومنشآت لممارسة نشاطاته المختلفة.

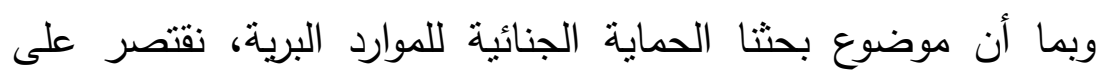
دراسة مكونات البيئة البرية دون سواها من عناصر البيئة البحرية والبيئة

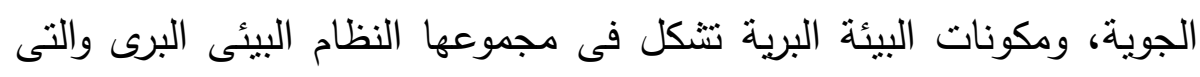

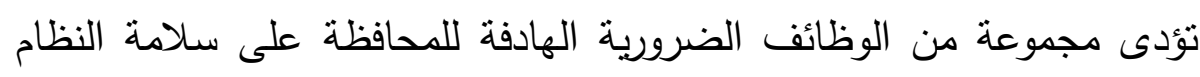

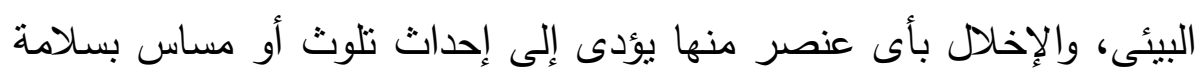

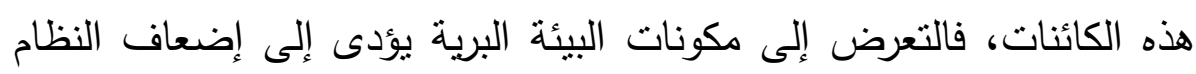

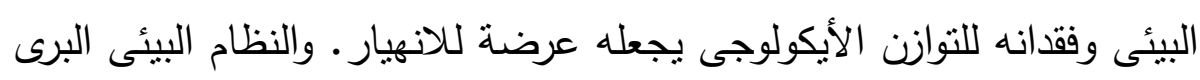
يتكوّن من عناصر حية وأخرى غير حية، وهى كالتالى:

أ- العناصر أو المكونات الحية للبيئة البرية وتتكون من:

- الغطاء النباتى للبيئة البرية: ويقصد به الغابات والمساحات الخضراء

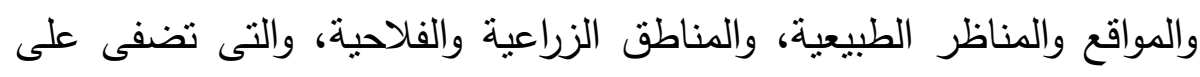

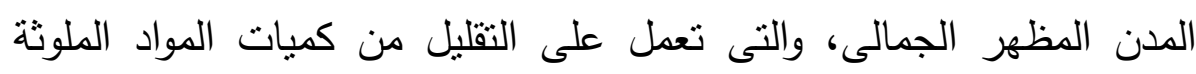

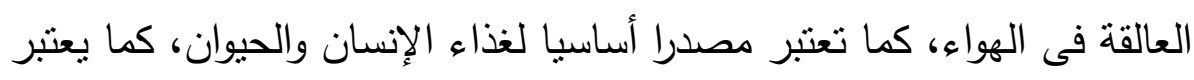

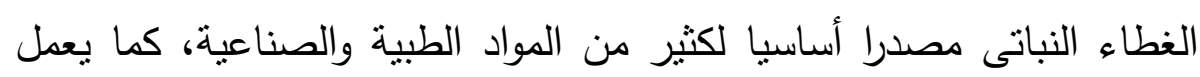
على حفظ الماء من التلوث ويحمى المحاصيل من نأثير الرياح.

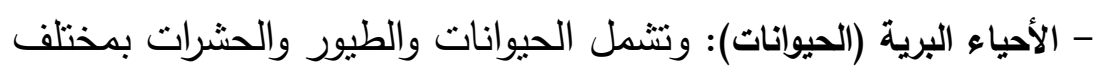

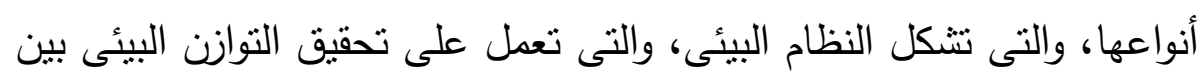
مختلف عناصر هذا النظام، حيث تنكل كل طائفة من هذه الأحياء البرية لئية 
حلقة أساسية فى سلسلة النظام الغذائى، كما تعمل على المحافظة على

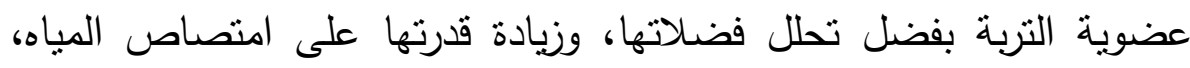

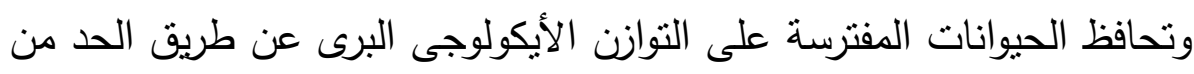
زيادة الحيوانات العشبية التى تتناسل بسرعة ، كما تعمل الطيور والحشرات

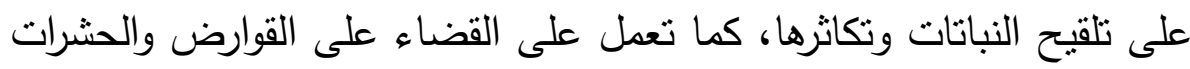

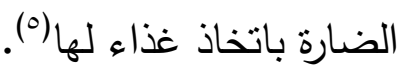
وفى مجال حماية العناصر الحية للبيئة البرية فى أوروبا قامت الدول

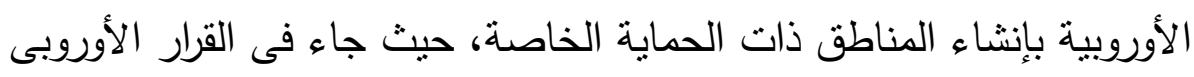

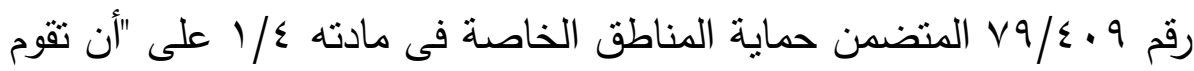

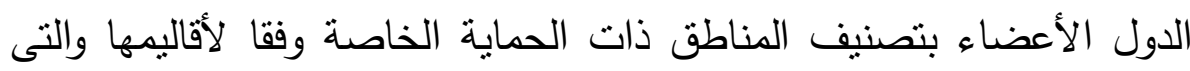

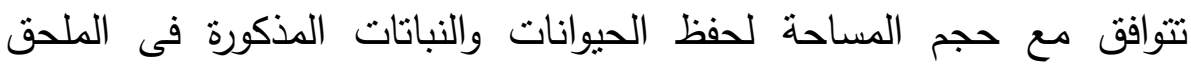

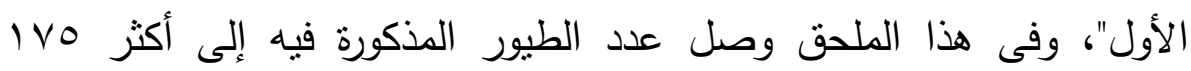
فصيلة، منها المهاجرة وغير المهاجرة(").

\section{ب- العناصر أو المكونات غير الحية للبيئة البرية}

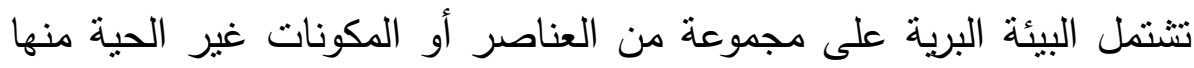

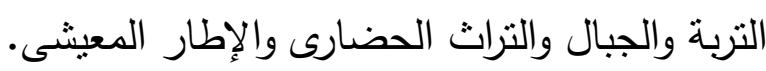
- الترية أو الأرض: تعتبر من أهم عناصر البيئة البرية أو عليها تقوم

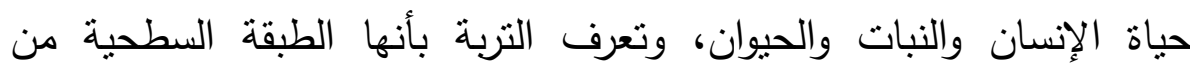
الأرض التى تصلح لنمو النباتات وممارسة الإنسان لنشاطاته الفلاحية. تنكل ولتهل

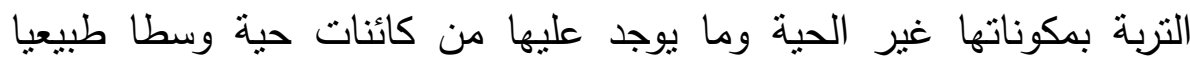
ونظاما بيئيا متكاملا ومتوازنا، ومحلا لأنشطة التتمية الاقتصادية. 
وقد كرس مشروع الميثاق العالمى للطبيعة وبرنامج الأمم المتحدة للبيئة لعام 9 التزام الإنسان والدول والمنظمات الدولية بعدم إهدار الموارد الطبيعية وتبديدها وعدم استغلالها على نحو يتجاوز قدرتها على التجديد والمحافظة على إنتاجية التربة وتتميتها، من خلال تدابير تكفل استمرار

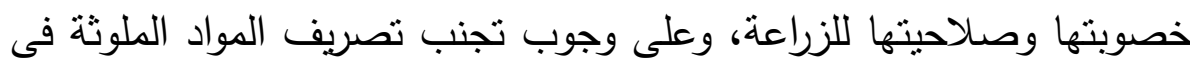
النظم الطييعية ومنها التربة، وضرورة إصلاح المناطق التى تدهورت بفعل الأنشطة الإنسانية وإعادة استغلالها (V).

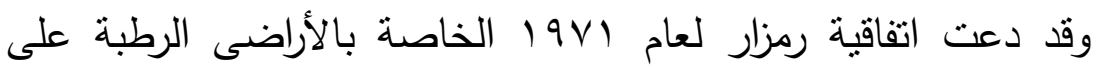

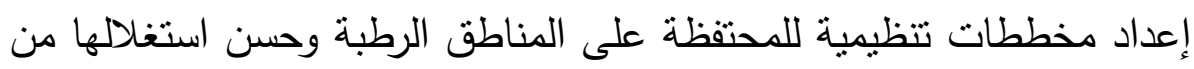
دون إفراط، وذلك من خلال اتخاذ تدابير تحول دون إحداث تغيرات بالظروف

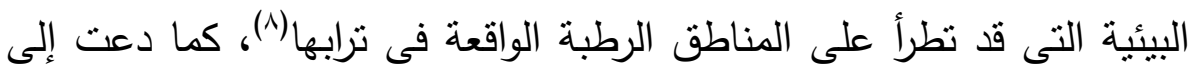
وضع قوائم تتضمن تسجيل المناطق الرطبة فى أقاليمها، وتسييرها بطريقة تؤدى إلى المحافظة عليها، وبإعلام مكاتبها بكل تغيير فى خصائصها الأبكولوجية، والعمل على وقف الزحف المطرد على الأراضى الرطبة، وتأكيد

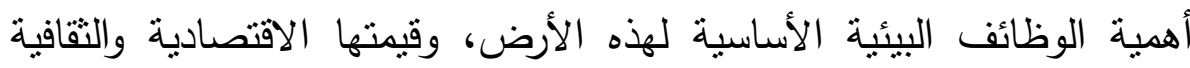

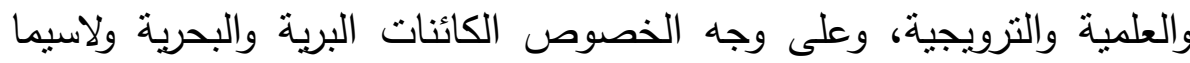
الطيور المائية(9). تعتبر التربة نراث مشترك بين الأجيال الحاضرة والمستقبلة، إلّا أنها أصبحت تعرف استنزافا غير مسبوق بسبب عوامل طبيعية وبشرية، تتمنل

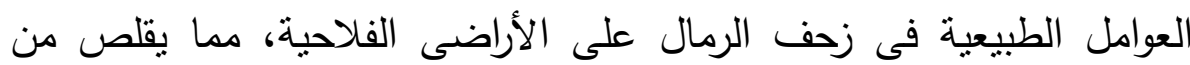

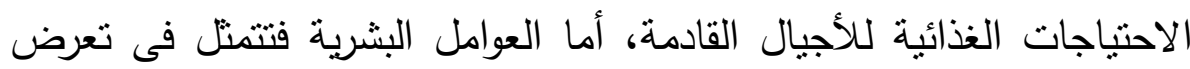
كثير من الأراضى الفلاحية للبناء المطرد عليها. 
- البيئة الحضرية: ويقصد بها كل ما قام الإنسان بتشييده كالبناءات

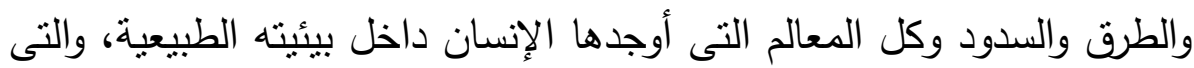

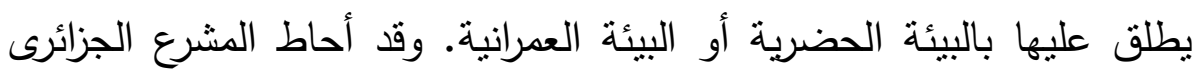

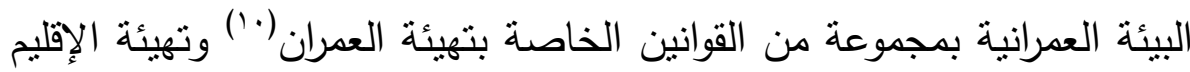
وتتميته المستدامة(').

كما وضع المشرع الجزائرى مخطط شغل الأراضى بوصفه أداة للتخطيط

العمرانى، فهو يحدد بدقة القطاعات المعنيّة بالبنية الحضرية.

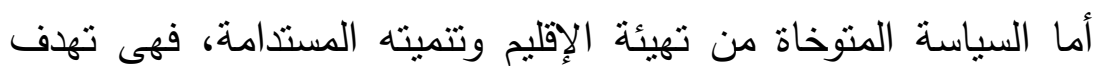

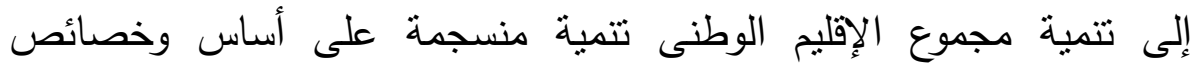
ومؤهلات كل فضاء جهوى، من خلال: - خلق الظروف الملائمة لتتمية الثروة الوطنية والتتشغيل. - نساوى الحظوظ فى الترقية والازدهار بين جميع المواطنين. - الحث على التوزيع المناسب والعادل بين المناطق والأقاليم لدعائم التنمية ووسائلها، باستهاف تخفيف الضغوط على السواحل والحواضر والمدن الكبرى، وترقية المناطق الجبلية والهضاب العليا والجنوب.

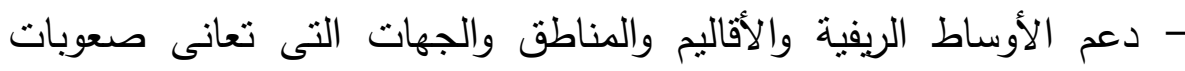
وتفعيلها من أجل استقرار سكانها. - إعادة توازن البيئة الحضرية وترقية الوظائف الجهوية والوطنية والدولية للحواضر والمدن الكبرى. - حماية الفضاءات والمجموعات الهشة أيكولوجيا واقتصاديا وتثمينها. - حماية الأقاليم والسكان من الأخطار المرتبطة بالتقلبات الطبيعية. 
- الحماية والتثين والتوظيف العقلانى للموارد التراثية والطبيعية والثقافية وحفظها للأجيال القادمة(r').

ومن أجل ضمان تهيئة الإقليم وتتميته نصت المادة ب من القانون

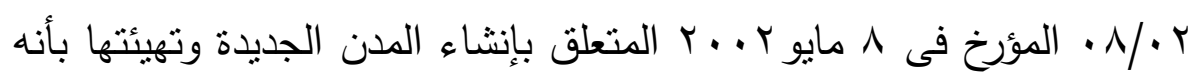
"يندرج إنثاء المدن الجديدة ضمن السياسة الوطنية الرامية إلى تهيئة الأقاليم

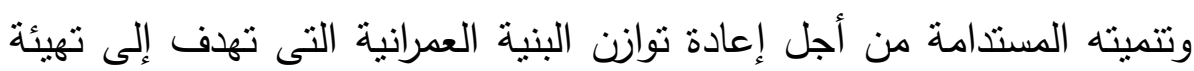
الإقليم وفق التشريع المعمول به". - التراث الحضارى: يعد التزاث الحضارى والتقافى والطبيعى من عناصر

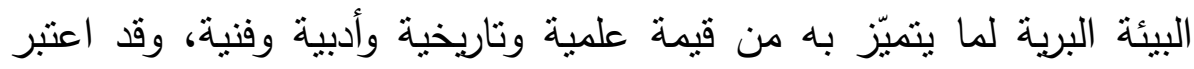

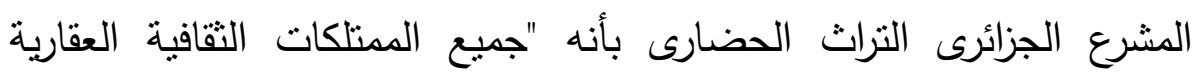
والعقارات بالتخصيص، والمنقولة الموجودة على أرض عقارات الأملاك الوطنية

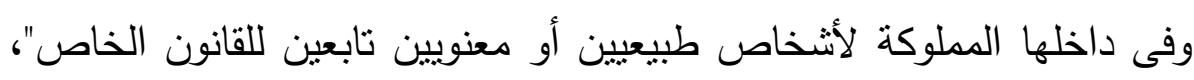

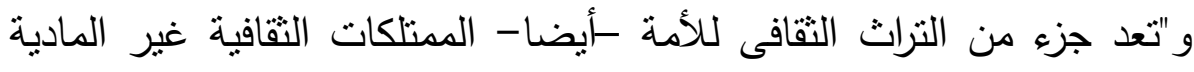

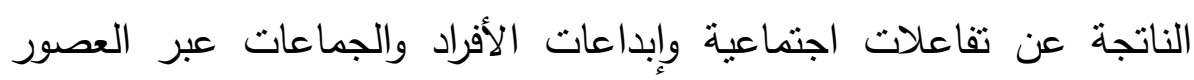

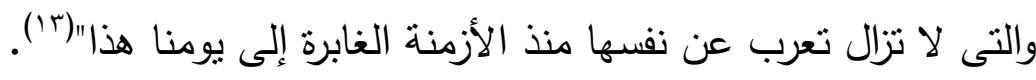

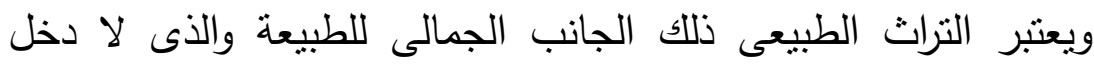

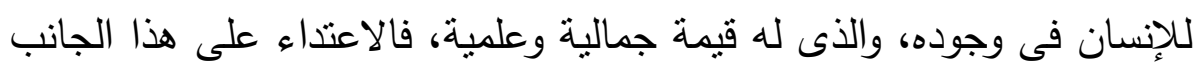

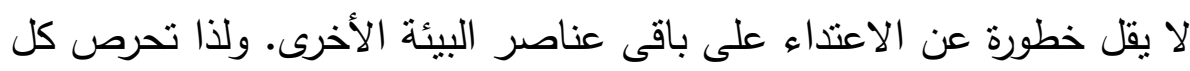

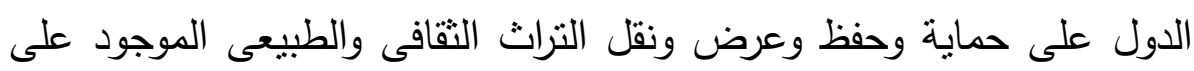

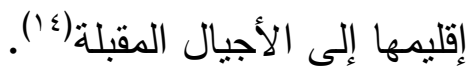




\section{r- هفهوم جريمة البيئة البرية وخصائصها}

يقصد بالجريمة بأنها "كل خرق أو انتهاك لقاعدة قانونية محمية بجزاء جنائى"، كما أن الجريمة البيئية تعنى "كل خرق لالتزام قانونى بحماية البيئة، وهى تتكل

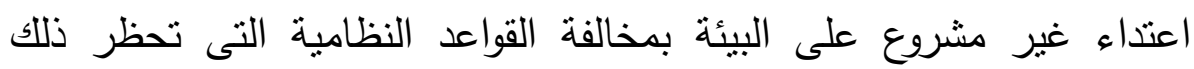

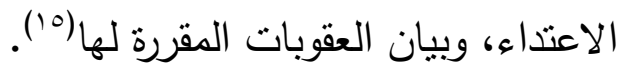

\section{أ- التعريف الفقهى لجريمة البيئة البرية}

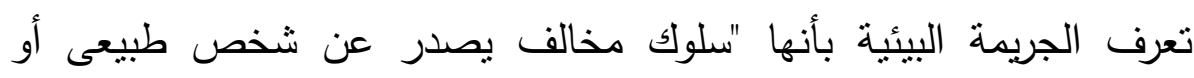

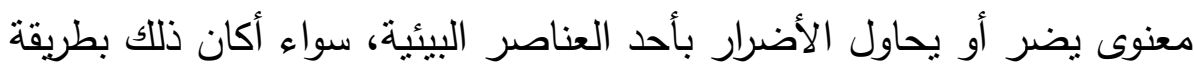

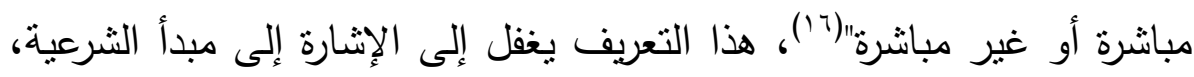

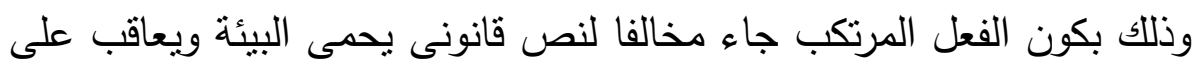

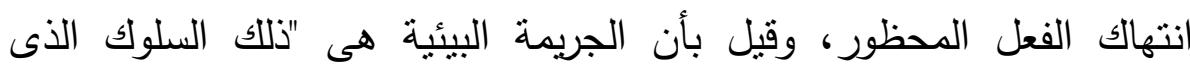

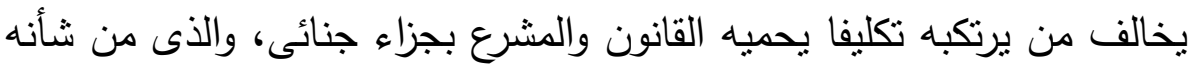

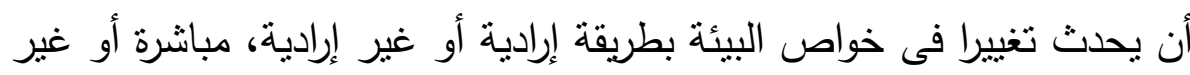

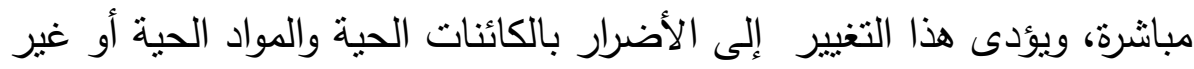

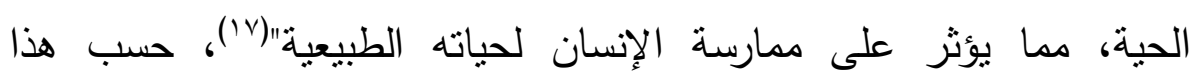

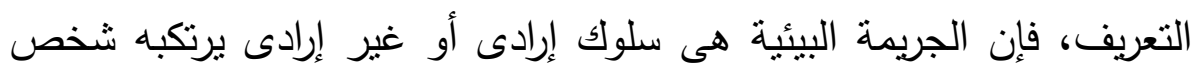

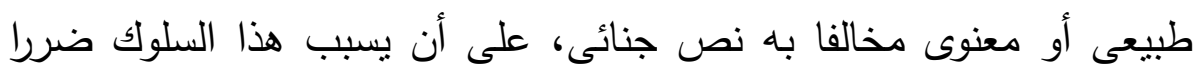
يلحق بالبيئة الحية أو غير الحية معرضا لها للخطر مانه وقيل عنها: "قام كل شخص بسبب إهماله أو طيشه أو تهاون منه بطريقة مباشرة أو غير مباشرة بتوقيع أضرار بصحة الإنسان والحيوانات

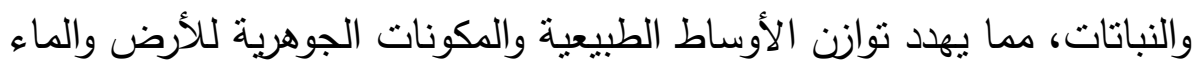
والهواء"(1)، تقوم الجريمة البيئية عند خرق التزام قانونى يتعلق بحماية البيئة، 
سواء أكان هذا الخرق بإتيان سلوك إيجابى أو سلبى، ويترتب عليه نتيجة

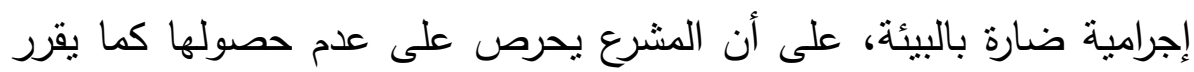

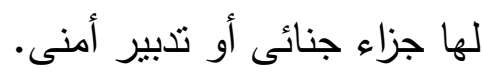

ونكون الحماية المباشرة للبيئة من خلال تدخل قانون العقوبات والقوانين

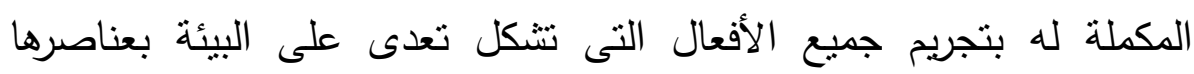

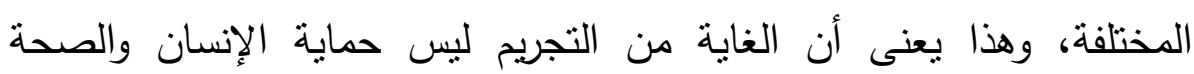

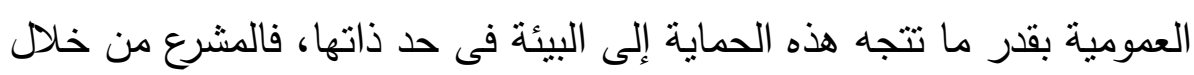

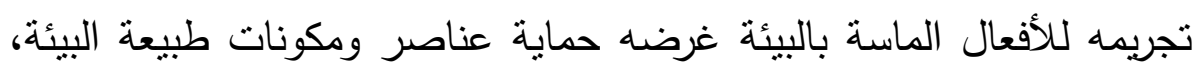
وما يؤدى إلى الإخلال بتوازنها. بينما يرى اتجاه فقهى ثان أن حماية الإنسان هو الغاية من تجريم الإنيا.

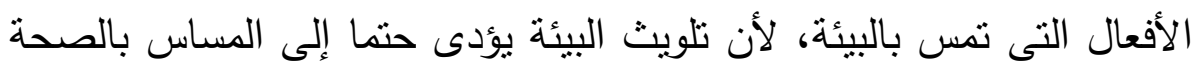

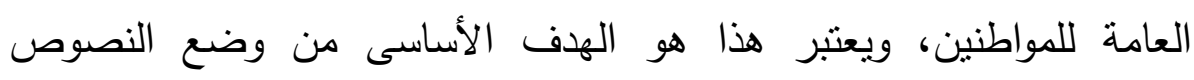
القانونية النى تجرم الاعتداء على البيئة من أجل حماية الإنسان وضمان حقان الإنه فى بيئة سليمة نظيفة وصحية.

\section{ب- التعريف القانونى الجريشة البيئية}

إن مبدأ الثرعية الجنائية يقتضى وجود نص الجينية قانونى سابق، يحظر فعل

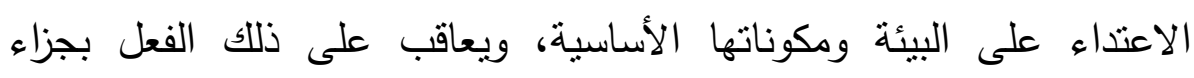
جنائى، فى إطار هذا الفرع نتعرض إلى القوانين الغربية الحامية للبيئة البرية ثن

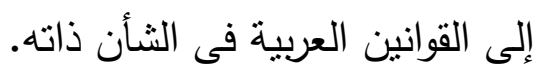


- حماية البيئة البرية فى القوانين الغربية

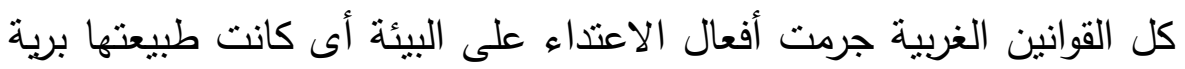

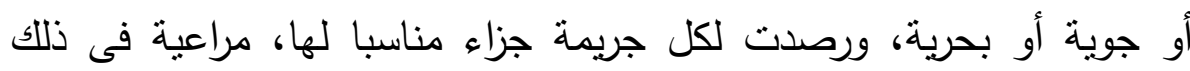

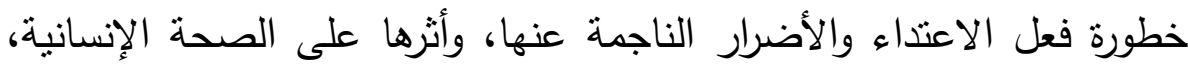
والكائنات الحيوانية، وهذا ما نراه فى القوانين التالية:

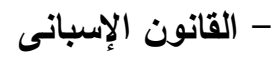
جاء مجرما ومعاقبا على المساس بالبيئة فى تعديله لقانون العقوبات لعام

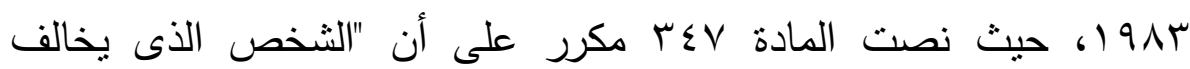
القانون والتنظيم المتعلق بحماية البيئة وينسبب بطريقة مبانشرة أو غير مباشرة

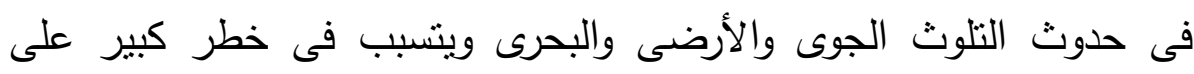

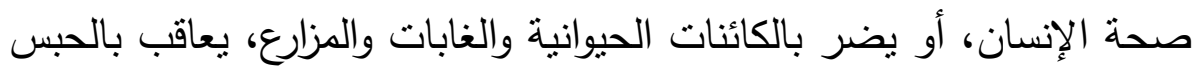

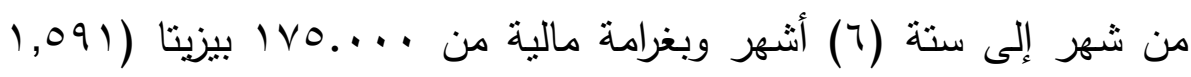

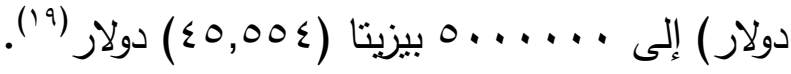
- القانون الإيطالى نص قانون العقوبات الإيطالى على حماية الصحة العامة للمواطنين، وذلك من خلال تجريمه نشر الأوبئة وتعريض الصحة للخطر، وذلك بمقتضى المادة

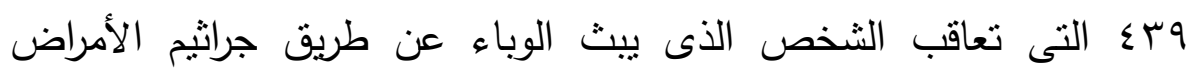

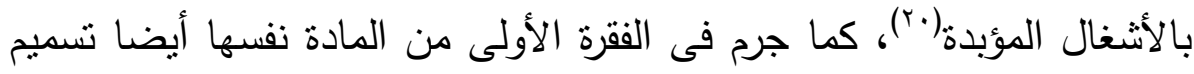

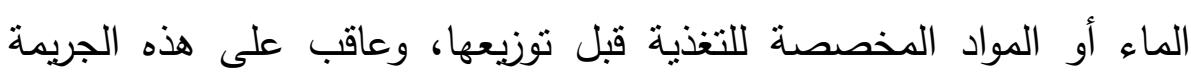
بالسجن لمدة 10 سنة، وفى حالة الوفاة تكون العقوبة الأشغال الثاقة المؤبدة،

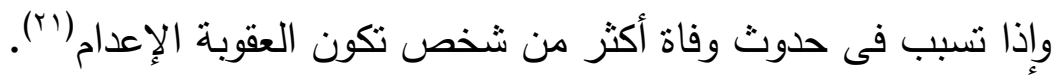




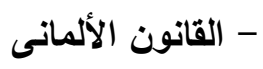

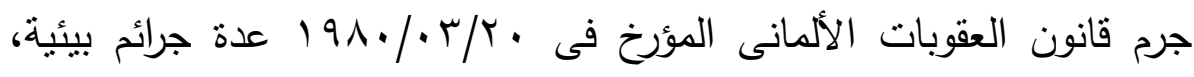

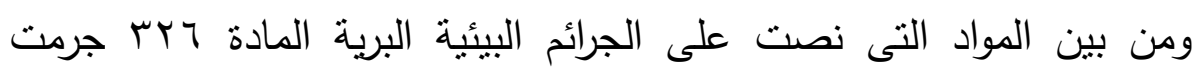

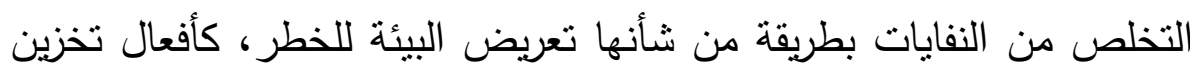

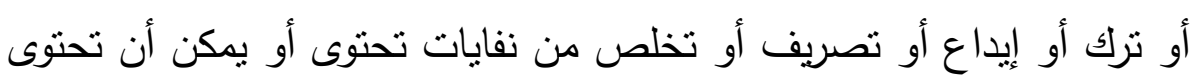

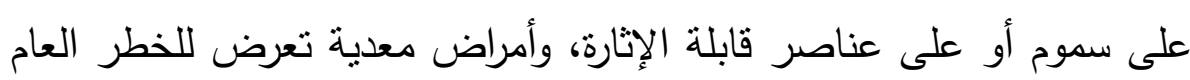

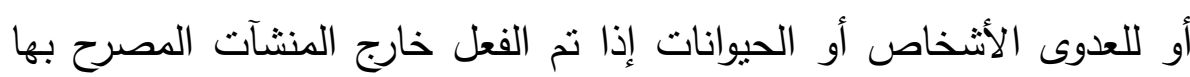

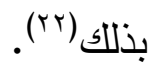

- القانون الفرنسى كان المشرع الفرنسى من الأوائل الذين جرموا إلقاء أى نوع من المخلفات التى التى

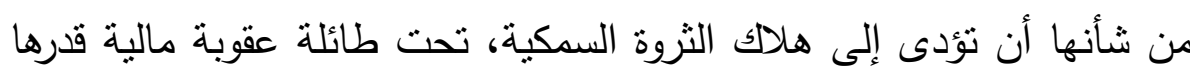

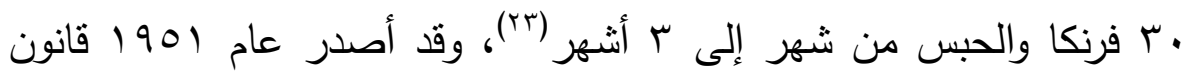
حماية الصحة العامة الذى دعا فيه إلى إنشاء محطات تتقية وتصفية التهية مياه الصرف الحضرى من كل المخلفات والنفايات المؤثرة على الصحة العامة، الصاءة

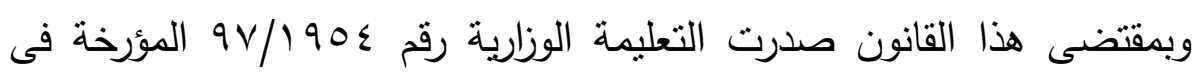

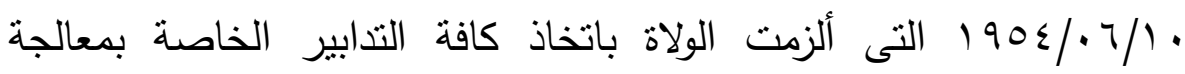

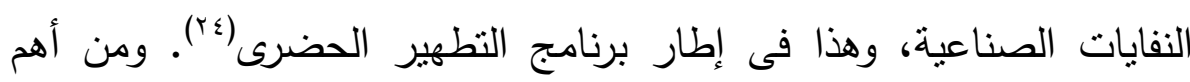

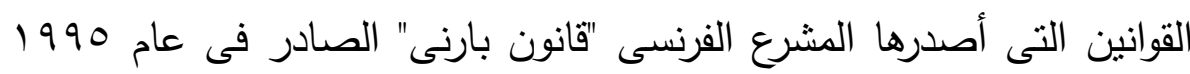
المتعلق بالوقاية من التلوث وتسيير النفايات والأخطار الطبيعية. - القانون اليابانى جاء قانون البيئة اليابانى لمواجهة المخلفات الصناعية الكبرى، وذلك من خلا لهابل

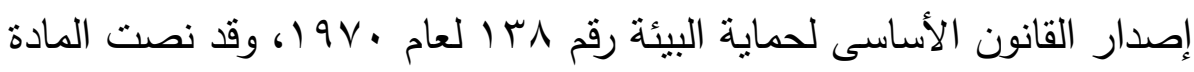


r منه على "أن المؤسسات الصناعية مسئولة عن اتخاذ الاحتياطات اللازمة

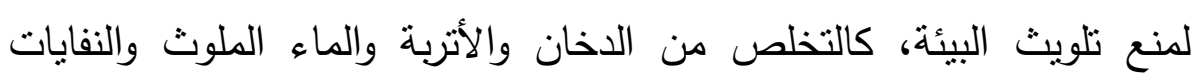

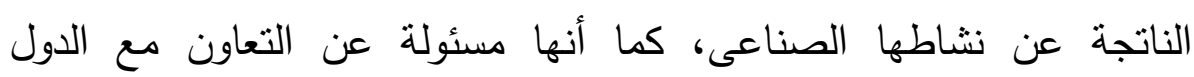

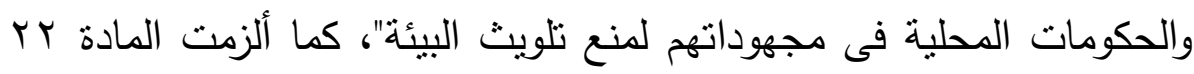

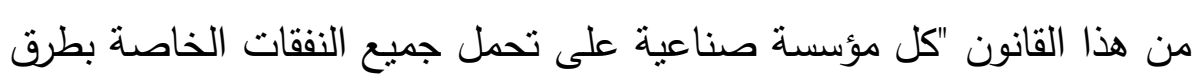

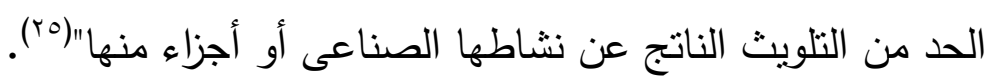

\section{جـ جماية البيئة البرية فى القوانين العربية}

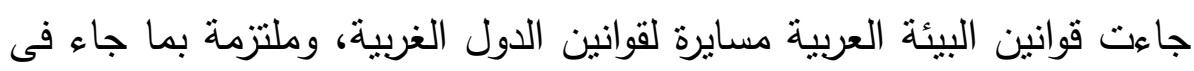

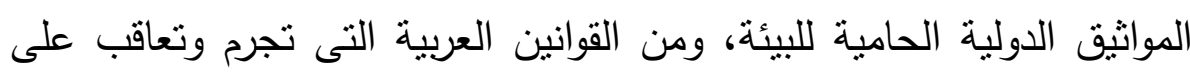
أفعال الاعتداء على البيئة نذكر النماذج الثالية:

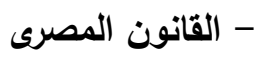

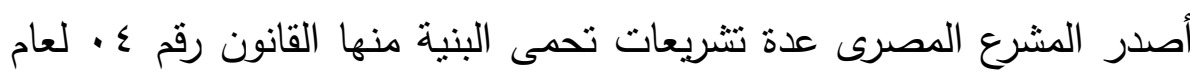

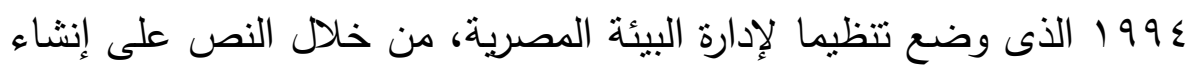

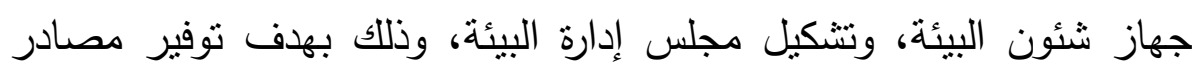

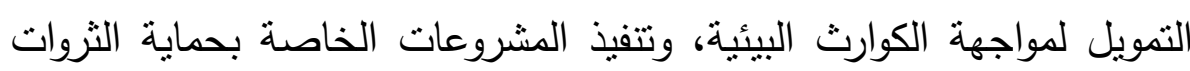
الطبيعية، وإنثاء وتثغيل الرصيد البيئى، وإدارة المحميات الطبيعية.

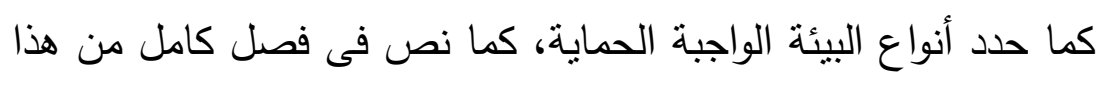

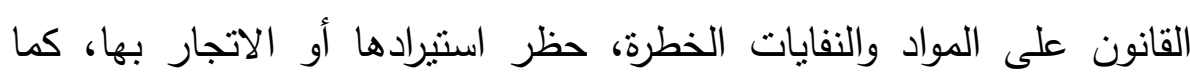

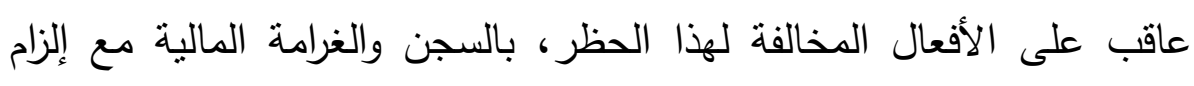
مستورد النفايات الخطرة بإعادة تصديرها عل نفقته الخاصة. 
كما حظر قانون المحميات الطبيعية كل الأعمال التى من شأنها أن

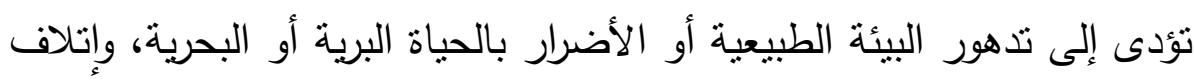

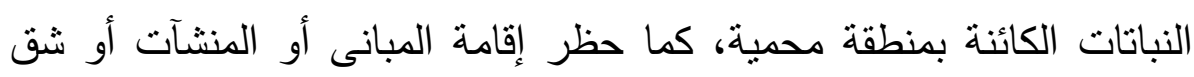

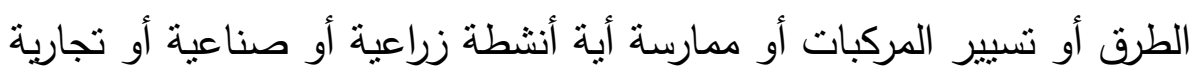

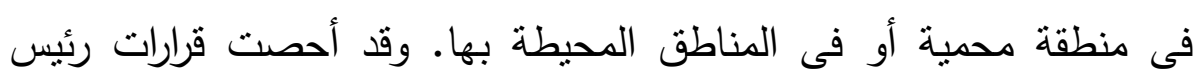

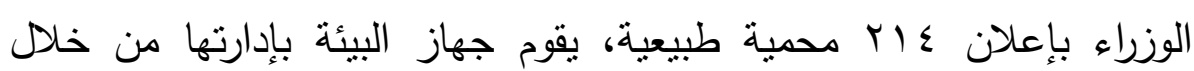

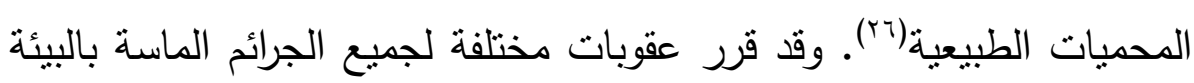
وبخاصة تلويث البيئة، إحداث النفايات الخطرة، والأضرار بالبيئة البرية والبحرية والجوية. - القانون السورى

نص فى كثثر من مواد قانون العقوبات على جرائم البيئة منها: - - جرائم إضرام النار قصدا في الأبنية والمصانع والإحراج والغابات والبساتين والمزروعات.

- جرائم تضر بصحة الإنسان أو النباتات أو الحيوانات كالتسبب فى انتشار

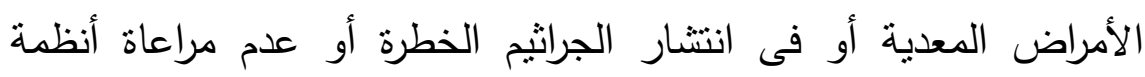
السلامة بكل الأوبئة والأمراض والحئ الحيوانات الضارة. - جرائم التعدى على الحيوانات والمزروعات كقتل الحيوانات وتسميمها وإساءة ولاءة معاملتها. - جرائم قطع وإتلاف الأشجار والمزروعات ورعى وإطلاق الحيوانات فى المى الأراضى المحمية.

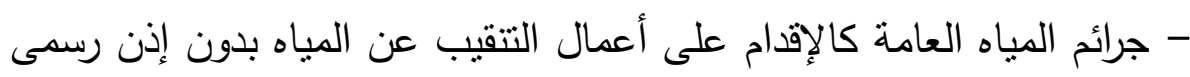
أو حصرها أو تلوثيها أو التعدى على ضفاف الثعاف مجارى المياه العامة 
والمستنقعات والبحيرات أو على حدود ممرات أقنية الرى والتصريف، والقيام

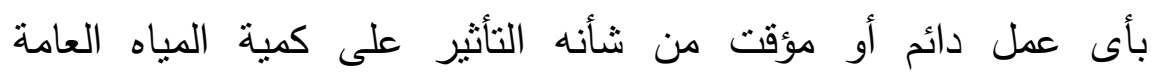

$$
\text { وجريانها (rV) }
$$

وقد عاقب على كل المخالفات التى تمس البيئة البرية والبحرية والجوية،

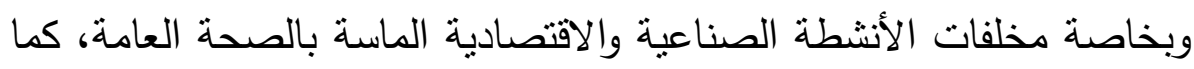
اتخذ مجموعة من التدابير الاحتياطية لمنع التلوث أو الحد من انتشاره.

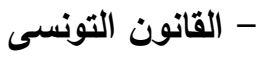
أصدر المشرع التونسى عدة قوانين لحماية البيئة، حيث أنثأت الدولة التونسية

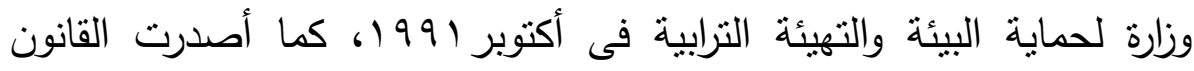

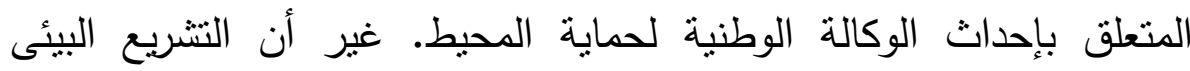

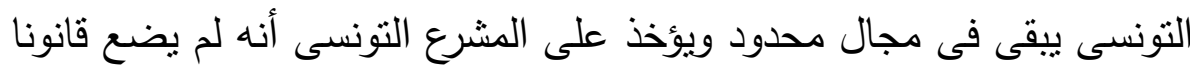

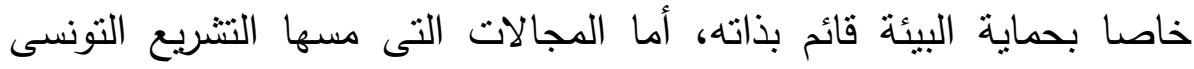

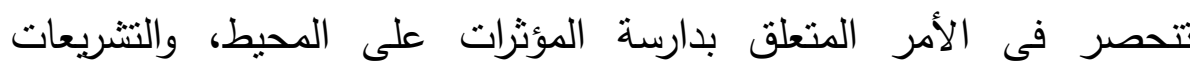
العمرانية، والتشريعات المتعلقة بالبيئة الطبيعية. وقد وضعت الدولة التونسية عدة مؤسسات تهنم بحماية البيئة منها، وزارة البيئة والتتصية المستدامة، وزارة الصحة، وزارة الفلاحة، وزارة الاقتصاد الوطنى،

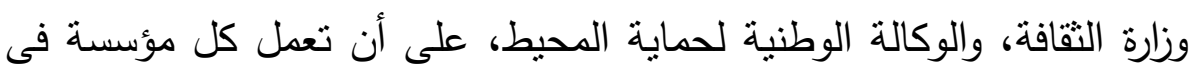

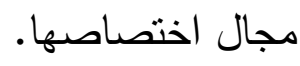
-القانون البحرينى نص المشرع البحرينى على نوعين من الحماية الجنائية للبيئة المباشرة منها وغير المباشرة، وقصد بالحماية المباشرة للبيئة عن طريق تجنئ تجريم جميع الأفعال

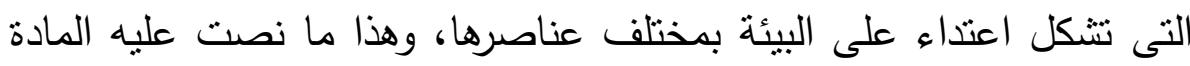


rا إ من قانون العقوبات البحرينى بقولها "يعاقب ... كل من أتلف أو نقل أو

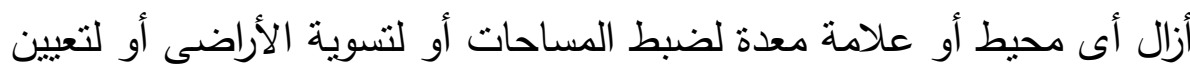

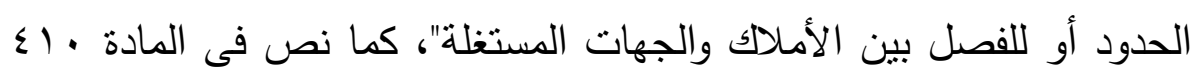
على أنه "يعاقب: أولا- من قطع أو اقتلع أو أتلف شجرة أو طعما فى شجرة أو قشرها بكيفية تميتها.

ثانيا- من أتلف زرعا قائما أو أى نبات أو حقلا مبذورا أو بث فيه نباتا ضارا.

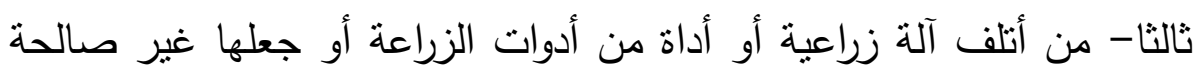
للاستعمال بأية طريقة". وقد نص فى المادة / 1 إ من نفس القانون على أنه "يعاقب:

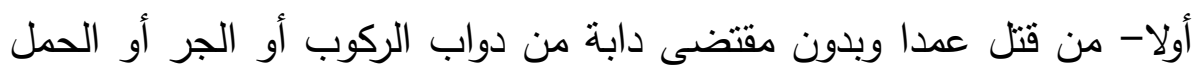

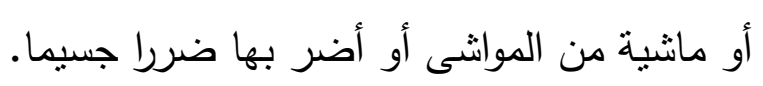

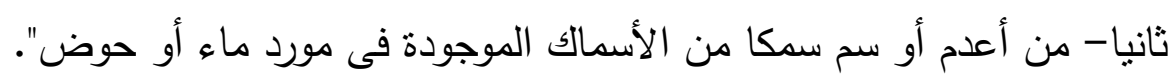

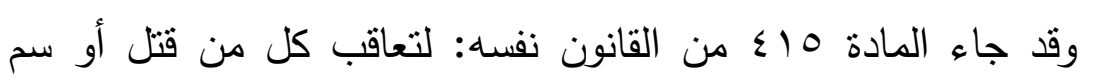

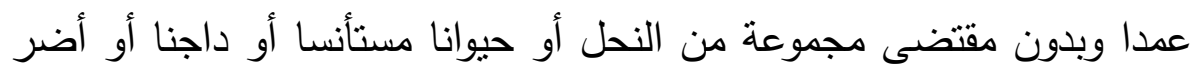

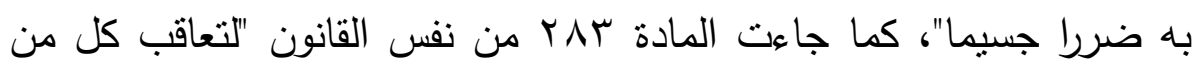
عرض عمدا حياة الناس أو سلامتهم للخطر بوضعه مواد أو جراثيم أو أثنياء

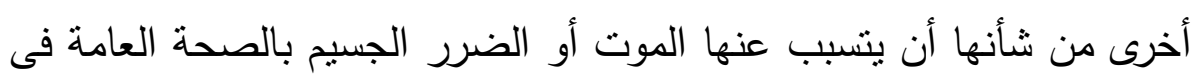

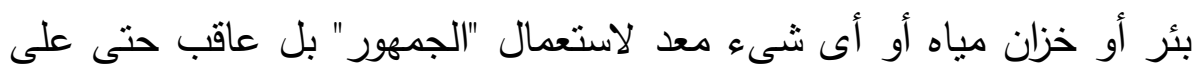

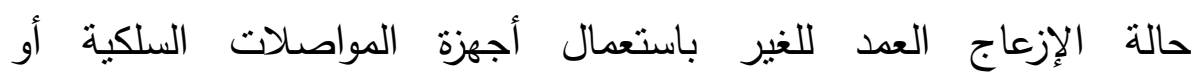
اللاسلكية (^^). 
أما النوع الثانى من الحماية الجنائية غير المباشرة للبيئة، وقد خص بها

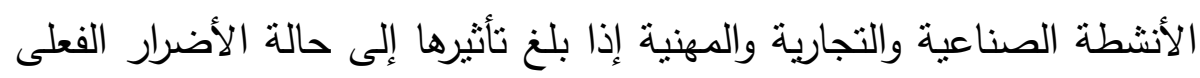

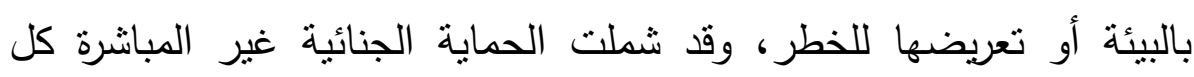
أفعال التلوث للمياه والهواء، وذلك بقصد المحافظة على البيئة النظيفة والارتقاء

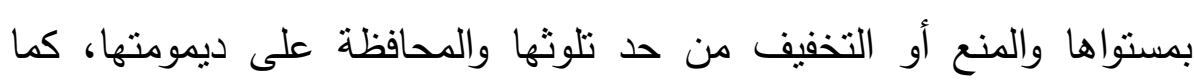
حرص على توفير الحماية للثروات الطبيعية. - القانون الجزائرى -

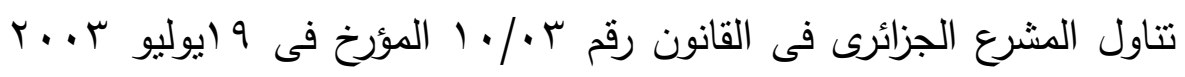

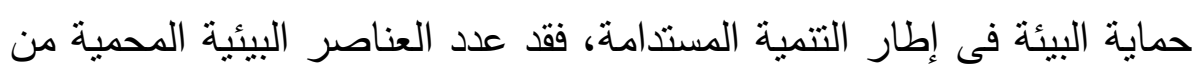

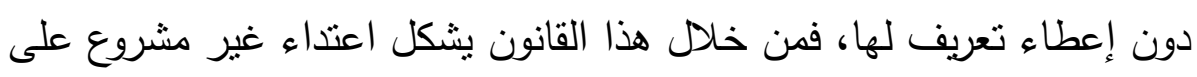

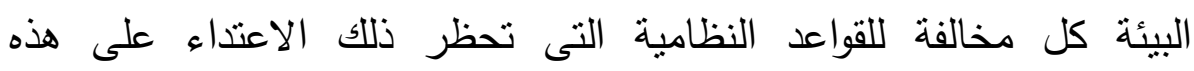
العناصر ، وبيان العقوبات المقررة لها، وبذلك يكون المشرع الجزائرى حدد أركان

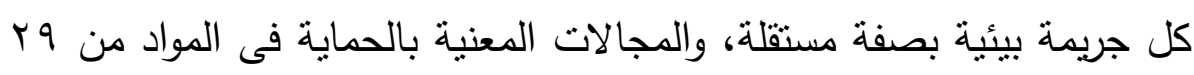
إلى عَ، وقد خصت بالذكر المناطق الخاضعة إلى أنظمة خاصة كالمواقع والأرض والنبات والحيوان والأنظمة البيئية وبصفة عامة تلأك المتعلقة بحماية البيئة (99).

وقد شملت المجالات المحمية الطبيعية التامة، الحدائق الوطنية، المعالم الطبيعية، مجالات نسيير المواضع والسلالات، المناظر الأرضية والبحرية المحمية، والمجالات المحمية للمصادر الطبيعية المسيرة(·r). وقد عاقب المشرع الجزائرى على انتهاك حماية التتوع البيولوجى، وحماية التربة والهواء والجو، وحماية الماء والأوساط المائية، وحماية المؤسسات 
المصنفة، وحماية الإطار المعيشى، وقد حددت لكل جريمة العقوبة المناسبة

د- م- خصائص الجريمة البيئية

للجريمة البيئية مجموعة من الخصائص التى تميزها عن غيرها من الجرائم هى

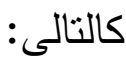

- الجريمة البيئية جريمة وقتية: يرتكبها شخص طبيعى أو معنوى، وتحدث نتيجتها الإجرامية بمجرد انتهاء السلوك الإجرامى، من أمثلنها جريمة قطع الأشجار ـ أما الجريمة المستمرة فإن تأثثرها يمتد لفترات طويلة من الزمن

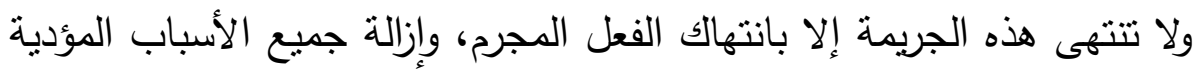
إليه، ومن أمتلنها جريمة الإشعاعات النووية.

- الجريمة البيئية جريمة مستحدثة: تهدف إلى حماية أنظمة بيئية

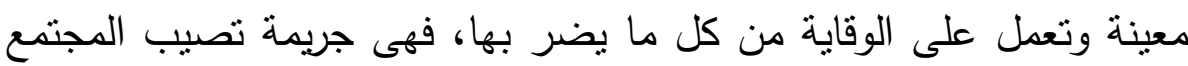
فى كيانه الاقتصادى والاجتماعى ومؤسساته المختلفة، لذا فهى تتميز بعدم النبات لخضوعها للتعديلات المتعاقبة.

- جسامة الكارثة: الاعتداء على البيئة فى الظروف العادية يختلف

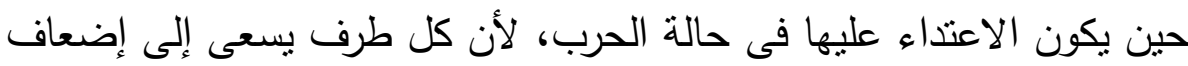

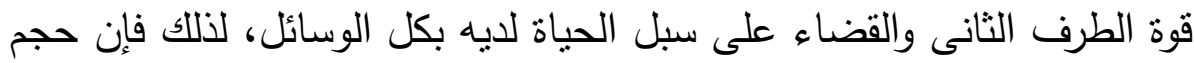
الكارثة سيكون كبيرا إذا ما كانت البيئة هى محل الاعنداء العسكرى، لأن

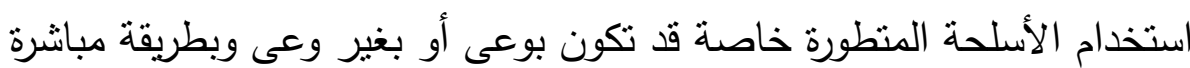
أو غير مباثرة مما يزيد من حجم الكارثة الإنسانية. 
- تعدد صور الضرر: يؤدى الاعتداء المتكرر على البيئة إلى تعدد

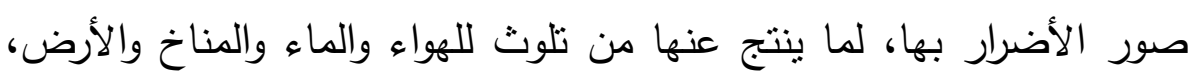
مما يؤدى إلى تغير النظام الكونى بأكمله، كما حدث عند ثقب طبقة الأوزون فى الهواء نتيجة تزايد الملوثات، وهى تلك الطبقة التى توجد أعلى الغلاف الجوى، والتى تحمى الإنسان والكائنات الحية من التعرض للأشعة فوق البنفسجية، وهذا ما حدث فى اليابان عند إلقاء القنبلة الذرية على هيروشيما وناكازاكى وما نتج عنهما من أضرار كثيرة ولمدة طويلة وضحايا عديدة.

- احتواؤها على عنصر المفاجأة: يعد عنصر المفاجأة من خصائص الجريمة البيئية، وذلك لعدم توقع الأضرار والمخاطر التى تصيب مكونات البيئة الطبيعية، مع استحالة تدارك الخطر الناتج عن الضرر الذى يحدث للبيئة التى كانت محلا للاعتداء، فقى النزاعات المسلحة يكون حجم الدمار الواقع على البيئة عنيفا، ويصعب تداركه أو السيطرة عليه.

- امتداد أثر الجريمة البيئية واتساع مسرحها: تعتبر الأضرار الناتجة عن الجربمة البيئية من الأضرار المستمرة لفترة طويلة، حتى يتم التكفل بها وإزالة أو الحد من مخاطرها، أو ما يعرف بإعادة الحال إلى ما كان عليه. فالجريمة البيئية من سماتها الاتساع خاصة فى الجو والماء مما بصعب السيطرة على مثل هذه الجرائم فى مدة قصبرة ومنع انتشارها. - الجريمة البيئية جريمة عبر وطنية: إذا كانت الجريمة البيئية العادية يسهل التغلب عليها واحتواؤها، فإن الجريمة البيئية الدولية يصعب احتوائها لانتشار آثارها المضرة بدولة أو دول متجاورة، من أمثلة ذلك جريمة إجراء التجارب النووية وجريمة الملوثات الكيماوية والإشعاعية، فالجرائم البيئية لا لاء 
تعترف بالحدود السياسية للاول والقارات، فهى جرائم عابرة للحدود، ومن هنا تكمن صعوبة السيطرة عليها.

\section{ب- أركان الجريمة البيئية البرية}

تقوم الجريمة البيئية بتوافر عناصرها الضرورية التى تسهم فى تكوين نموذجها القانونى، ويترتب عن تخلف أحد عناصرها عدم قيام الجريمة، فالجريمة البيئية تقوم على ثلاثة أركان أساسية، هى الركن الثرعى والمادى والمعنوى.

\section{أ- الركن الشرعى لجريمة البيئة البرية}

إن الثرعية الجنائية تقتضى وجود النص القانونى الذى يبين الفعل المكوّن للجريمة، ويحدد العقاب والتدابير الأمنية التى تفرض على مرتكبها، فوجود النص القانونى السابق على فعل الاعتداء، فى هذا إقرار لمبدأ شرعية الجريمة

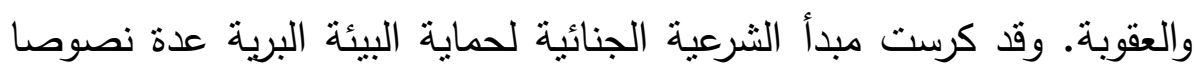
دولية ووطنية. وإن كانت النصوص الدولية خالية من الجزاءات الردعية

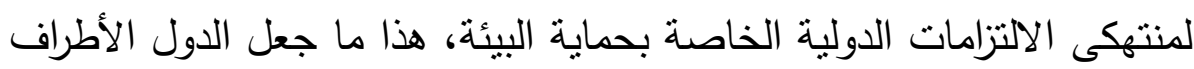
فى الاتفاقيات الدولية نسن قواعد قانونية تجرم وتعاقب على الانتهاكات المتعلقة

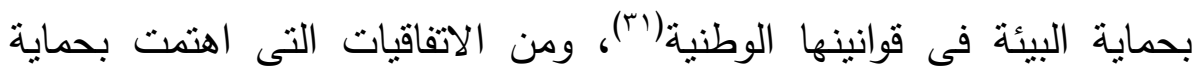
البيئة البرية اتفاقية الطيور المفيدة للزارعة لعام r •919، وبعد التعديلات الطارئة

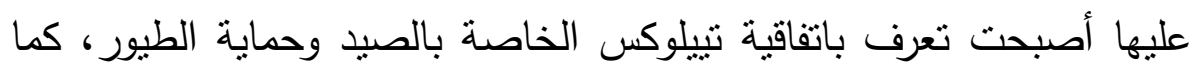
تعتبر الاتفاقية الإقليمية لندن لعام سبوا المتعلقة بحماية الحياة النباتية والحيوانية فى الطبيعة مكملة للاتفاقية السابقة لها، وذلك من خلا إضفاء حماية صارمة على بعض الأصناف الحيوانية البرية. 
وقد لعبت اتفاقية رمزار لعام /9V| دورا كبيرا فى حماية الأراضى الرطبة والعمل على وقف الزحف المطرد على هذه الأراضى، ثم جاءت اتفاقية

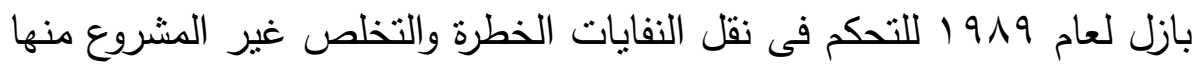

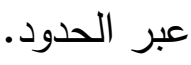

كما نم الاهتمام بالبيئة البرية فى الكثير من الإعلانات والمؤتمرات الدولية، من ذلك مؤتمر استوكهلم لعام 19VY، الذى نص على حق الإنسان فى العيش فى بيئة سليمة صحية ونظيفة، وتقع على الإنسان مسئولية حمايتها

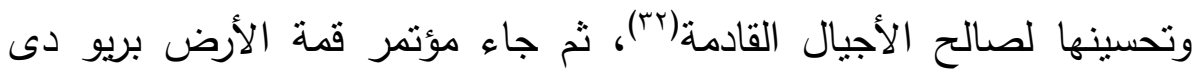

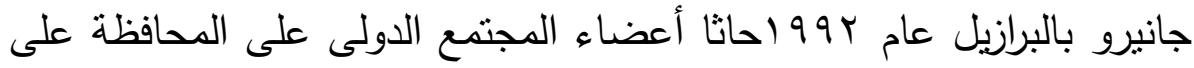

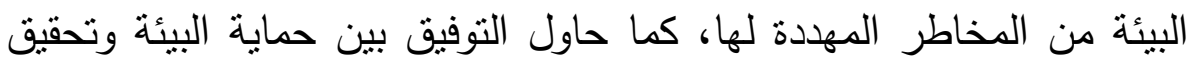

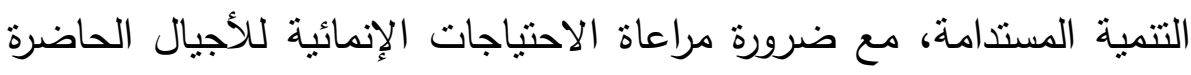

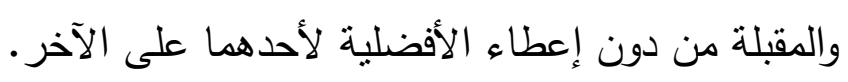

أما النصوص القانونية الوطنية المكرسة لحماية البيئة البرية، نجد هذه الهراه الحماية منصوصا عليها فى كل دسانير الدول، ومنها الدستور الجزائرى لعام 17. الذى نص على أنه "لا إدانة إلا بمقتضى قانون صادر قبل ارتكاب الفعل المجرم"، كما كرس الدستور نفسه حق الإنسان فى التمتع بييئة نظيفة وصحية وخالية من التلوث (rr). وقد جاء دستور المملكة العربية السعودية الصادر بمقتضى المرسوم الملكى رقم 1 • لعام ب991 199 على أن "تعمل الدولة على المحافظة على البيئة

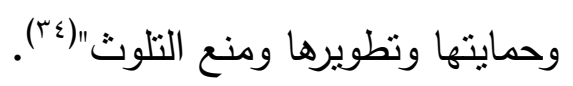

ومن النتريعات الغربية المكرسة لحماية البيئة فى دساتيرها نذكر دستور

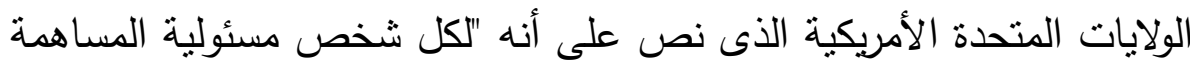


فى صيانة البيئة وتحسينها"، وهذا المعنى نفسه ورد فى "الدستور البرتغالى لعام

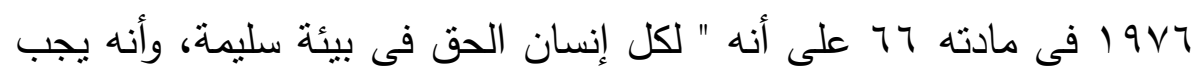

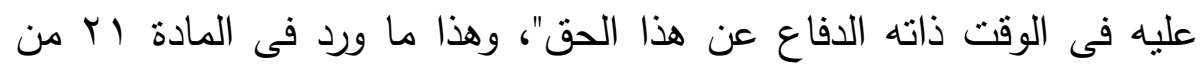
الدستور الهولندى التى نص على أن "يكون من مهام الدولة والمسئولين منع هادئ

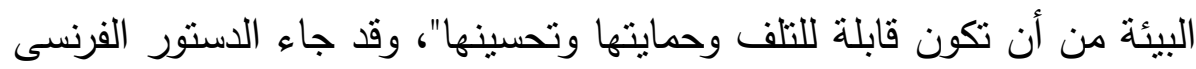

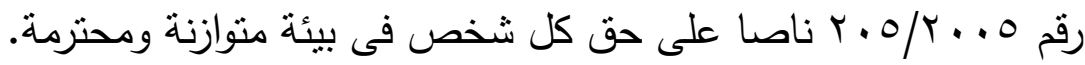

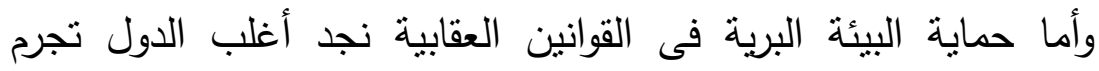
وتعاقب على خرق وانتهاك أحكام البيئة البرية والجوية والبحرية، وتعتبر الجزائر

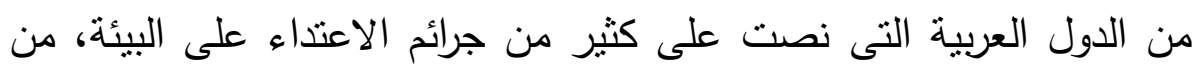
ذللك المادة NV مكرر 7 من قانون العقوبات التى تجرم وتعاقب على الاعتداء على المحبط، والمادة 97 ب/ء التى تجرم وتعاقب على إضرام النار فى الغابات أو الحقول، وقد اعتبرت جريمة الاعنداء على المحيط على أنها جريمة إرهابية،

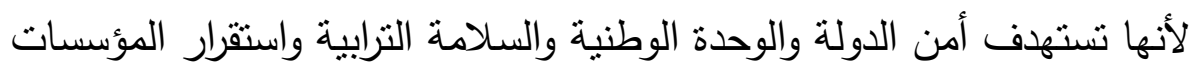

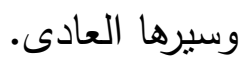

وقد أفردت بعض الدول حماية البيئة البرية بقوانين خاصة منها الولايات

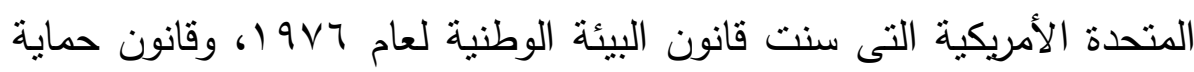

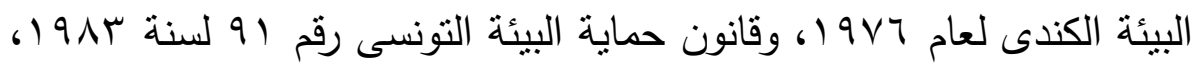
وقانون حماية البيئة الهصرى رقم ؟ • لسنة ع991، وقانون حماية البيئة الأردنى لعام r . . r، وقد ساير المشرع الجزائرى هذا الاتجاه بإصدار القانون

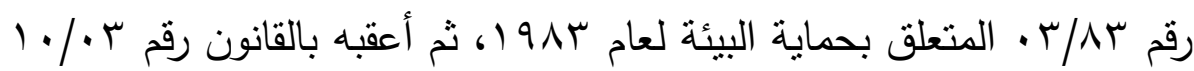
المتعلق بحماية البيئة فى إطار التتمية المستدامة. 
إن مبدأ الثرعية الجنائية يعرف توسعا فى هذا المجال ولاسيما عند وجود

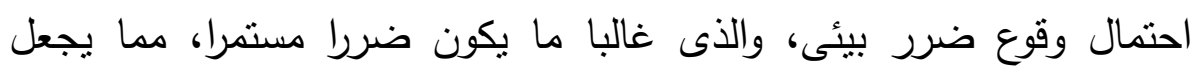

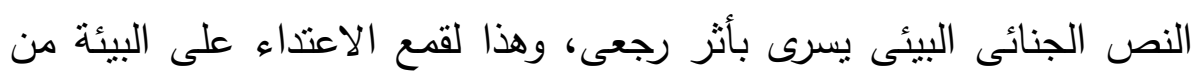

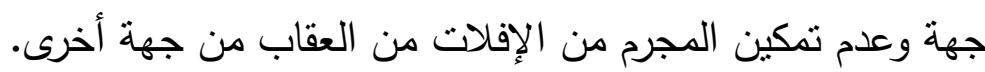

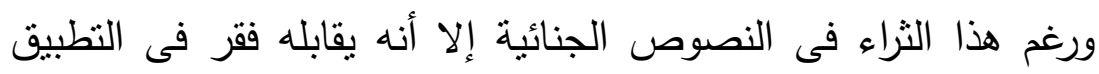

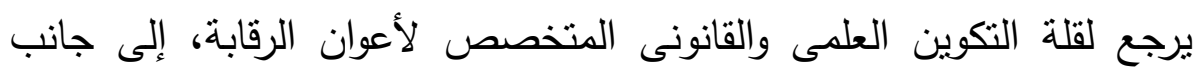

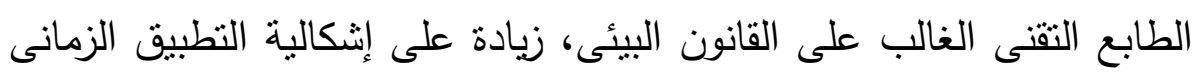
والمكانى للنص البيئى، وهذا كله نتيجة خصوصية الجريمة البيئية.

\section{ب- الركن المادى للجريمة البيئية البرية}

يشكل الركن المادى للجريمة البيئية المظهر الخارجى لانتهاك الالتزام القانونى

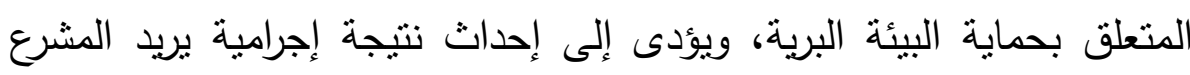

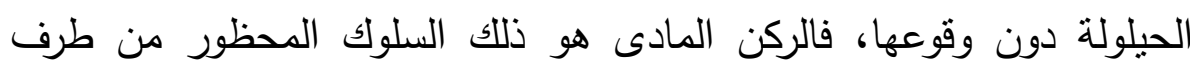

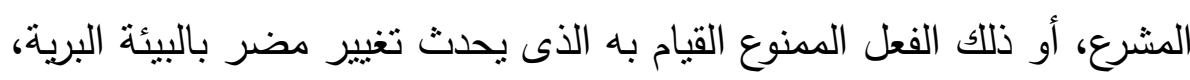

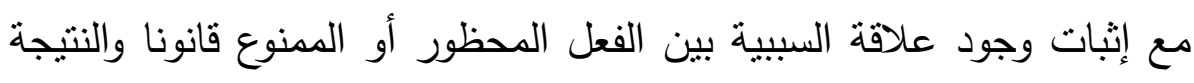
التى أدت إلى الأضرار بالبيئة البرية.

فالسلوك الإجرامى يتحقق عند قيام الجانى بفعل أو تصرف باليئة مخالف

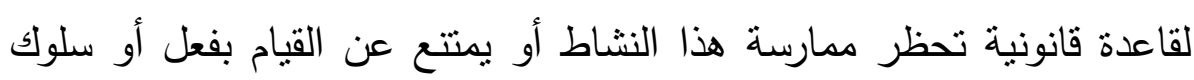

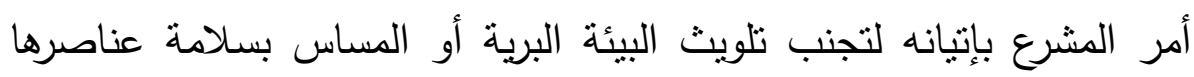
الطبيعية. يتكون الركن المادى للجريمة البيئية البرية من السلوك الإجرامى سواء أكان سلوكا إيجابيا أو سلبيًّا، ويترتب عليه نتيجة إجرامية مضرة بالبيئة البرية: وذللك على النحو التالى: 
- أن يكون الفعل إيجابيا: وهو ذلك السلوك المادى الذى يرتكبه

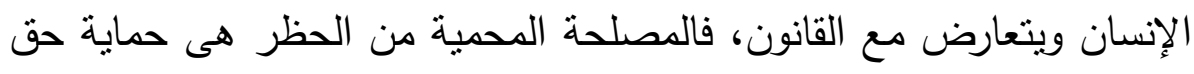

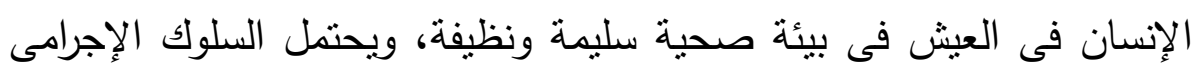

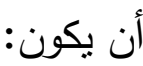
فعلا إيجابيا كتلويث البيئة البرية أو تدهورها أو المساس بسلامتها، من

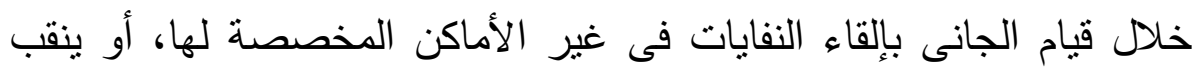

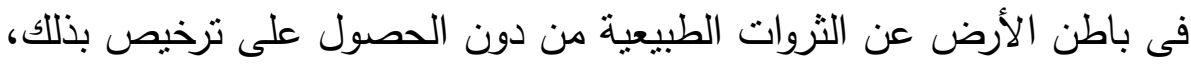

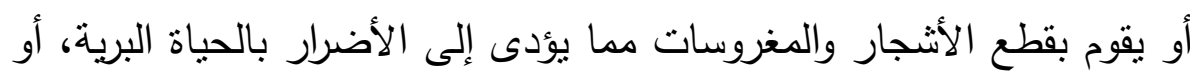
انقراض بعض أصناف الطيور والحيوانات النادرة. ومن التشريعات المقارنة التى تحظر الأفعال الإيجابية الماسة بتلويث الماتيث

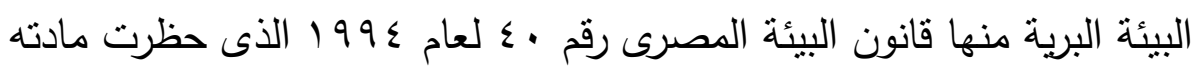

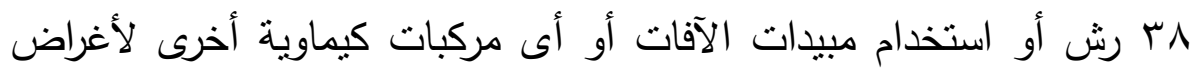
الزراعة أو الصحة العامة، فهذه الجريمة تقوم على فعل إيجابى، حيث يقوم الواله

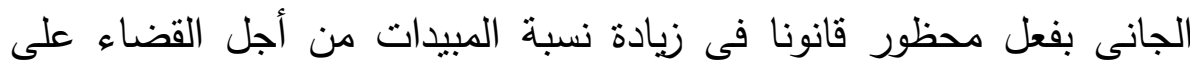
الآفات، مما يعرض فقدان التربة لبعض خصائصها البيولوجية.

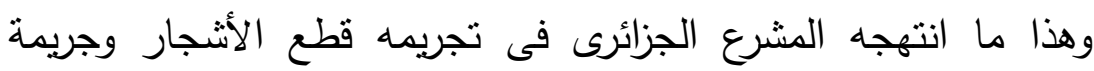

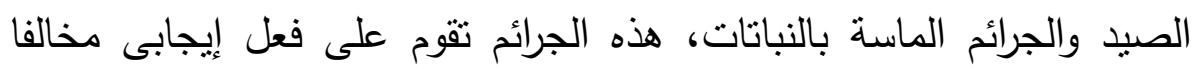

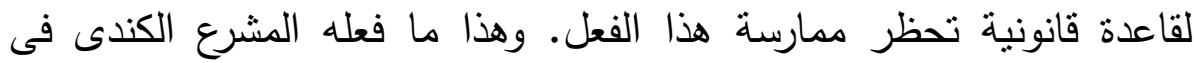

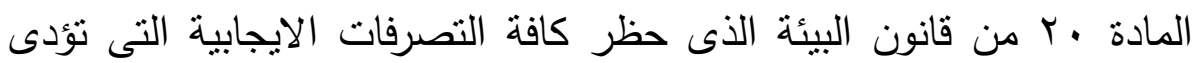
إلى تلويث البيئة وتدهورها، وذلك بالدخالفة لقواعد قانونية حامية لها.

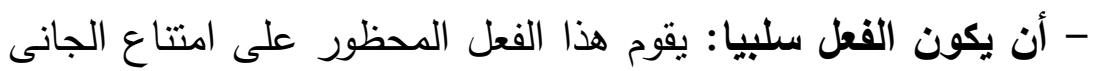

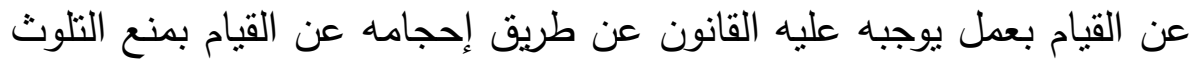


أو تهديد للبيئة البرية، ومن أمتلة ذلك امتتاع صاحب المنشأة عن اتخاذ التدابير اللازمة لمنع تسرب الغازات والأبخرة المضرة بالصحة الإنسانية.

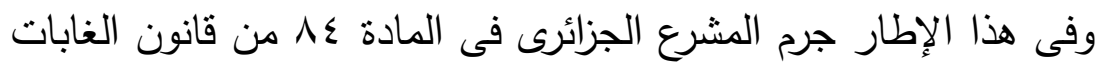

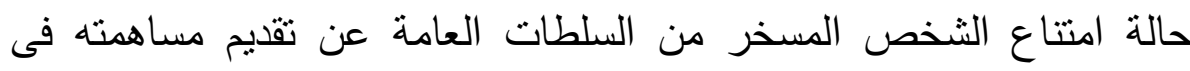

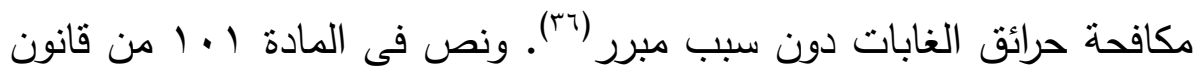

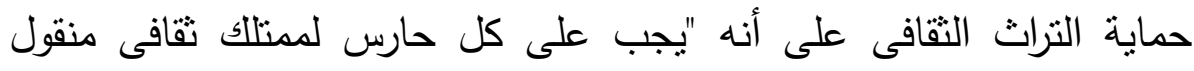

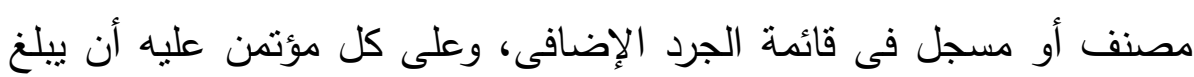

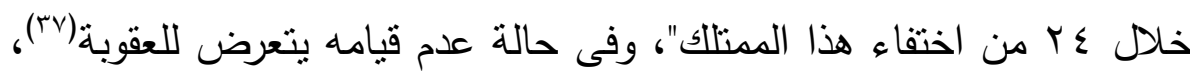
وما نص عليه فى المادة إ من القانون رقم 19/1 المتعلق بتسيير النفايات

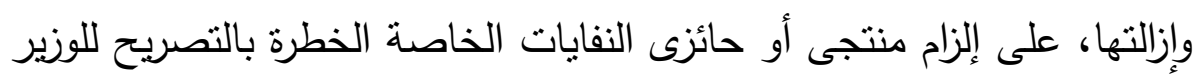

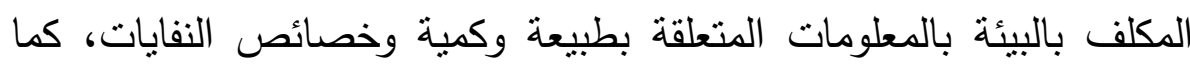

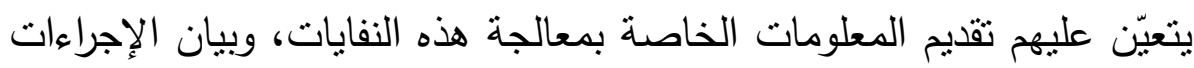

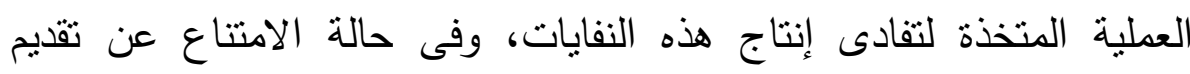

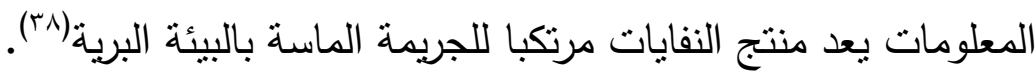

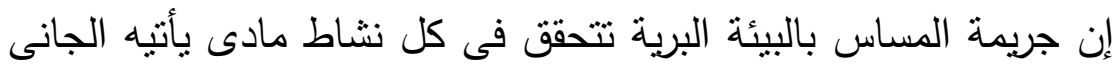

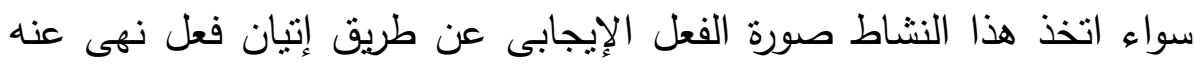

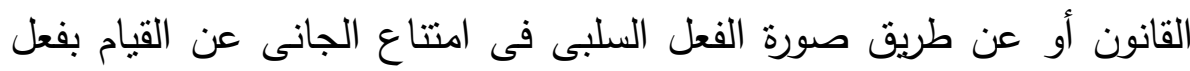

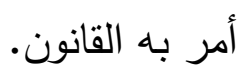
- حصول النتيجة الإجرامية الماسة بالبيئة البرية: حتى تقوم الجريمة الماسة

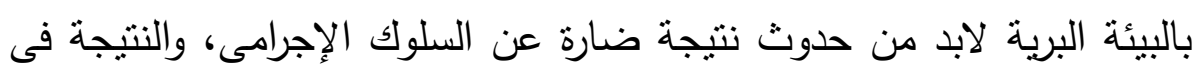

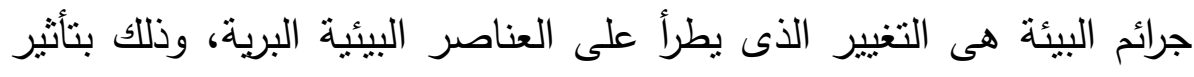
الفعل أو السلوك المحظور الذى يرتكبه الجانى. وتعرف النتيجة الإجرامية 
الضارة على أنها ذلك الأثز المترتب على السلوك الإجرامى الذى يضعه

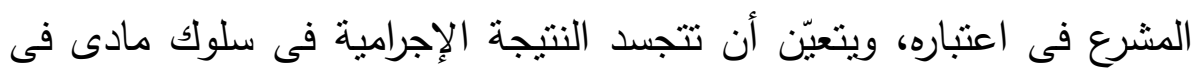

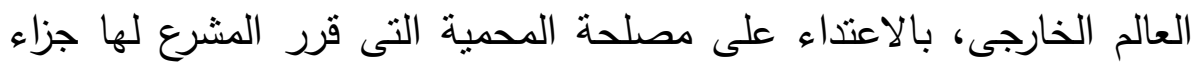

$$
\text { يوقع على مرتكب هذه الجريمة. }
$$

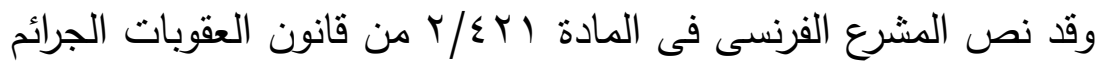

البيئية الخطرة، ولكنه لم يشترط اكتمال جريمة تلويث البيئة لتحقق النتيجة

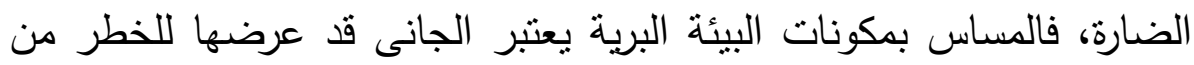

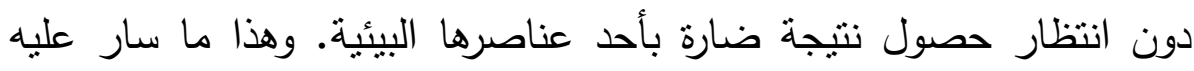

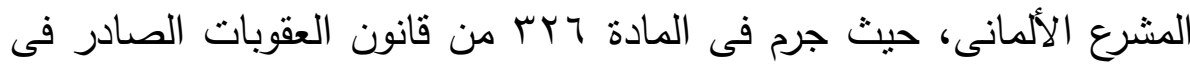

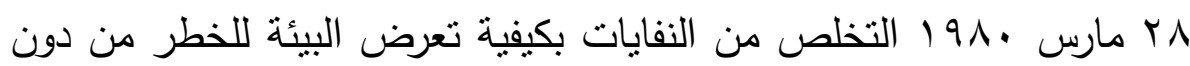

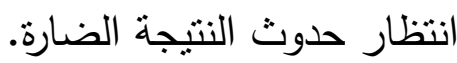

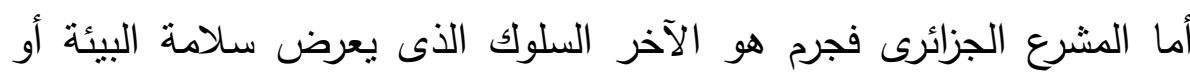

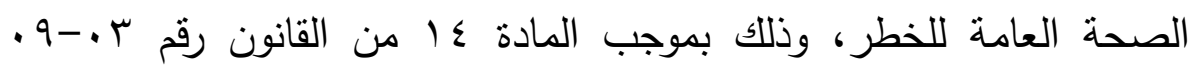
المتعلق بحظر استحداث وإنتاج وتخزين واستعمال الأسلحة الكيماوية، على أنه النه "يعاقب ... كل من يترك أو يرمى مواد كيماوية سامة(YV)، وتقوم مسئولية

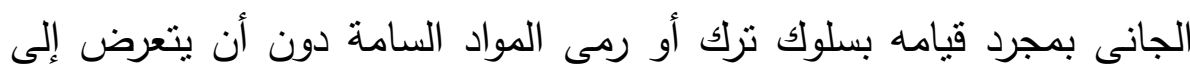

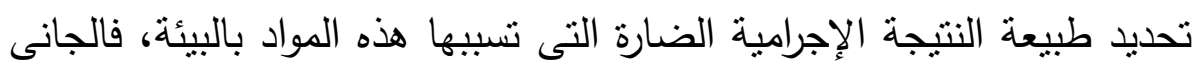

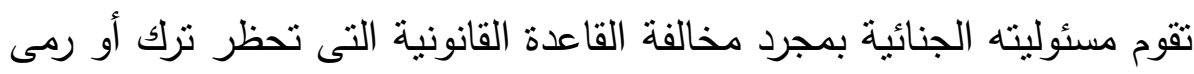
المواد السامة فى البيئة. - العلاقة السببية: يشترط لتحقيق العنصر المادى لجريمة البيئة البرية وجود

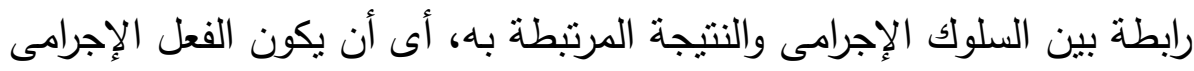

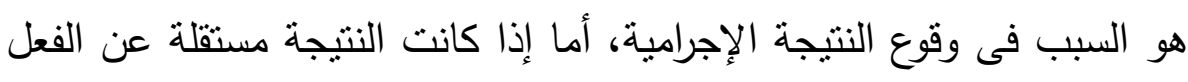


وأثتث فصلها عنه، فإن الكيان المادى للجريمة لا ينحقق، وبالثالى لا يمكن إسناد النتيجة الإجرامية إلى مرتكب الفعل الإجرامى.

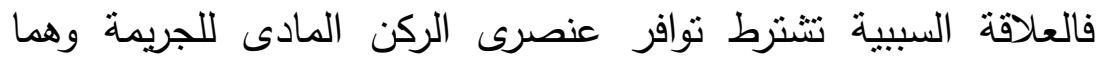

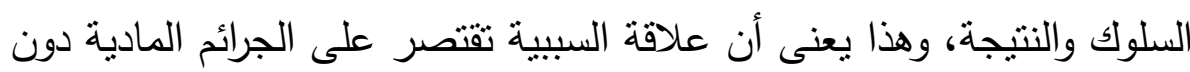

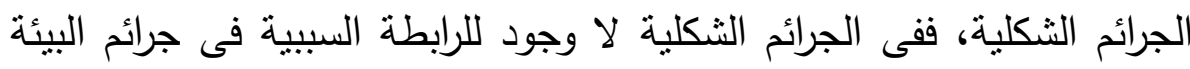

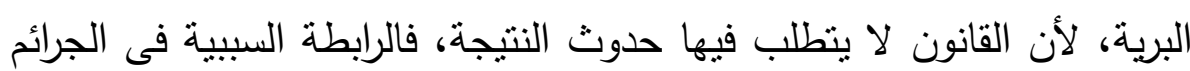

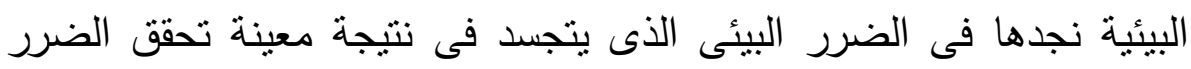
بالبيئة كالتشمم الناتج عن تلويث المياه بالمواد الكيماوية.

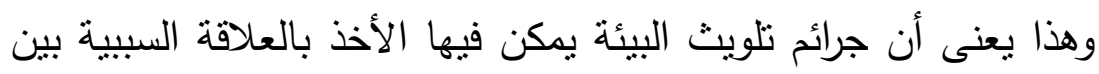
الفعل الإجرامى ونتيجته الإجرامية فى جرائم البيئة الضارة، أما جرائم البئية البئة

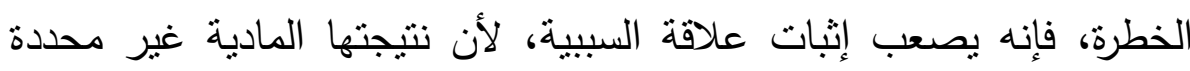

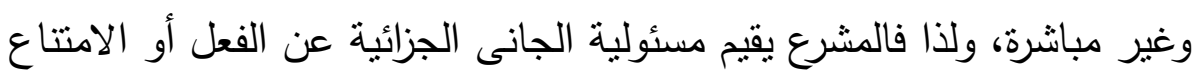

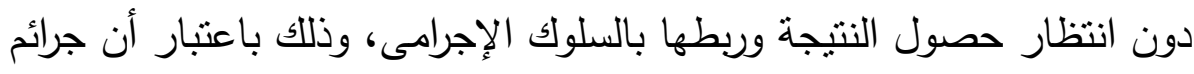

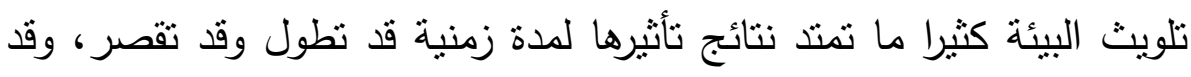

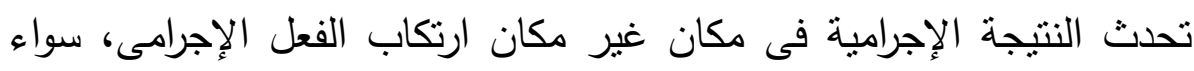

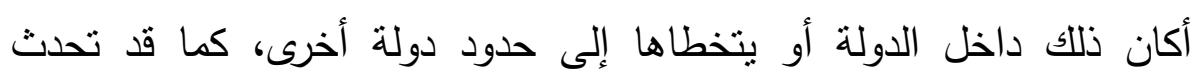

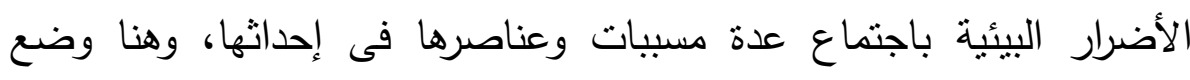

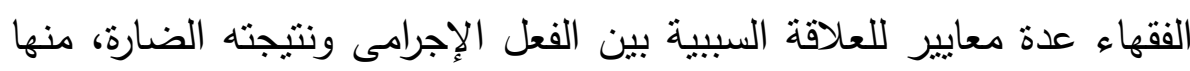
نظرية السبب المباثر ، نظرية السبب الأقوى، نظرية السبب الملائم، ونظرية العبادية

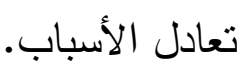

ولذا نجد أغلب التثريعات البيئية عمدت إلى إصدار نصوص بيئية خاصة بجرائم الخطر ، وذلك لوقوعها بمجرد إثبات السلوك دون الشتراط تحقق الثقات 
النتيجة، وتوفير أكبر قدر من الحماية للبيئة البرية، وهذا ما يضع حدا لصعوبة إثبات العلاقة السبيية بين السلوك والنتيجة.

\section{الركن المعنوى لجريمة البيئة البرية}

لا يكفى لقيام الجريمة البيئية ارتكاب فعل مادى يعاقب عليه القيهية القانون، وإنما

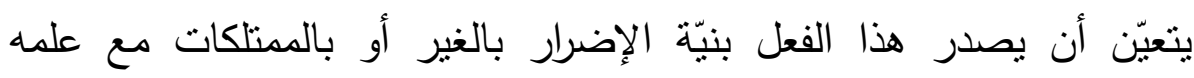

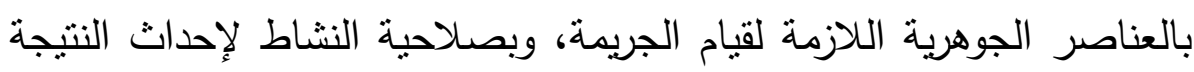

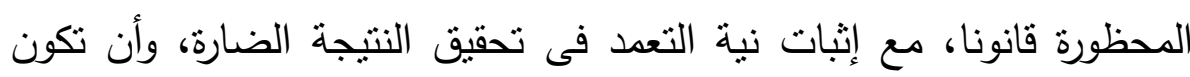

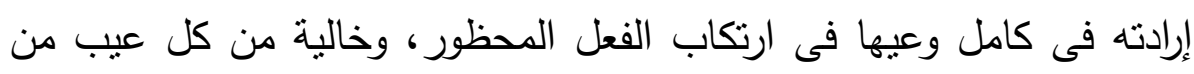

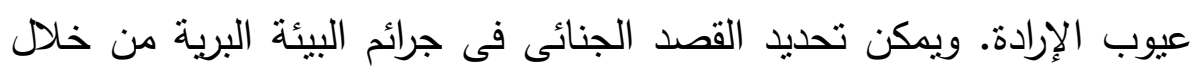

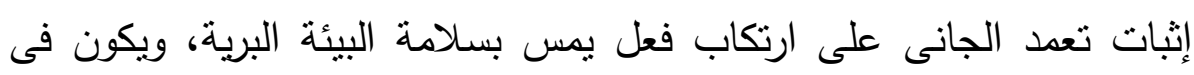
حالة ارتكابه للفعل المحظور على علم بذلك وتكون إرادته حرة وواعية.

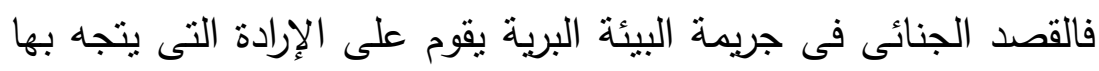

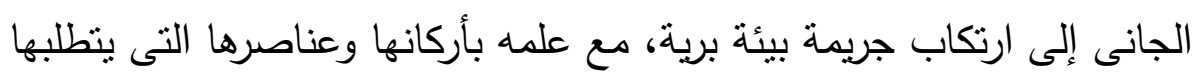

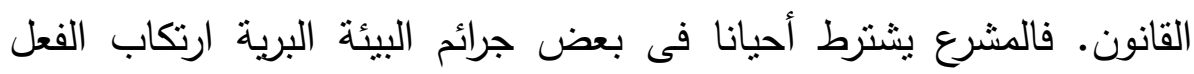

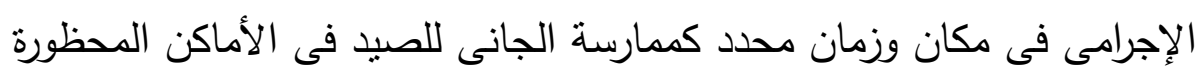
أو فى الأوقات المحظورة.

وقد يتخذ القصد الجنائى فى جريمة البيئة البرية عدة صور وأثنكال، وقد الأد يكون القصد مباشرا أو احتماليا، أو يكون عمديا أو غير عمديًا، وقد يكون عاما أو خاصا. 


\section{ثانياً: المسئولية الجزائية لجرائم البيئة البرية}

يكرس قانون البيئة الجزائرى حماية جنائية لكل مجال طبيهى، فهو يمنع

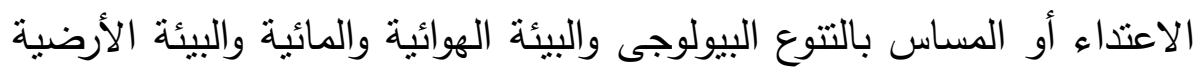

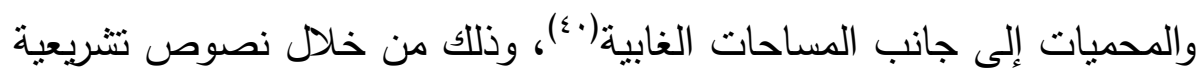

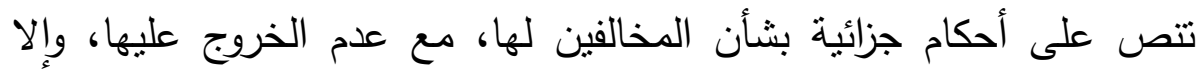
ترتبت الجزاءات المنصوص عليها فى قانون العقوبات بحسب بطان خطورتها وجسامتها إلى جنايات وجنح ومخالفات. وتقوم المسئولية الجنائية عن الجريمة فئونة البيئية البرية على الثخص الطبيعى أو المعنوى.

\section{ا - المسئولية الجنائية للشخص المرتكب جرائم البيئة البرية}

إذا تم إثبات الجريمة البيئية، يتطلب إسنادها إلى الثخص المرتكب إياها، والذى لا يعدو أن يكون شخصا طبيعيا أو شخصا معنويا، وهذا ما نحاول مناقتنه فى إطار الفرعين الثاليين.

\section{أ- المسئولية الجنائية للشخص الطبيعى}

يتحمل الثخص الطبيعى المسئولية الجزائية عن فعله الثخصى، إذا اثبت

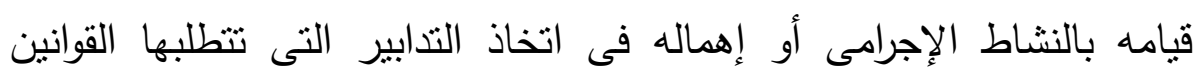
واللوائح، وهذا ما يعرف بمبدأ شخصية العقوبة، وهذا ما كرسه الدستور الجزائرى فى المادة rأ أمن دستور 999 ابقوله "تخضع العقوبات الجزائرية

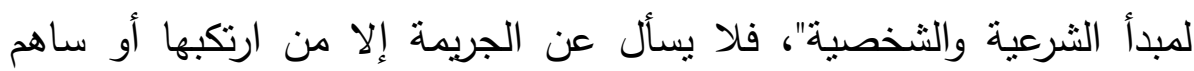

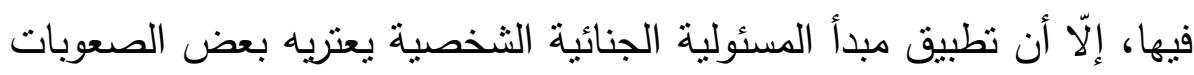
من الناحية العطلية، وذلك أن تحديد الفعل الثخصى بستوجب تحديد

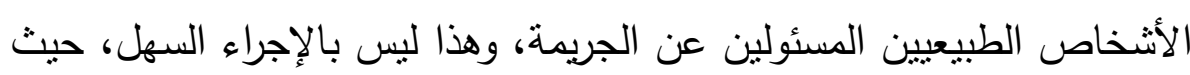


يصعب فى جرائم البيئة البرية تحديد الثخص مرتكب الجريمة وتحميله

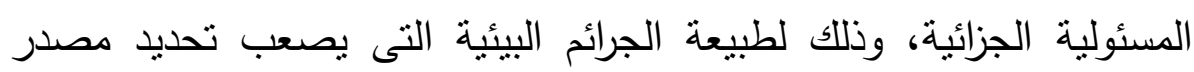

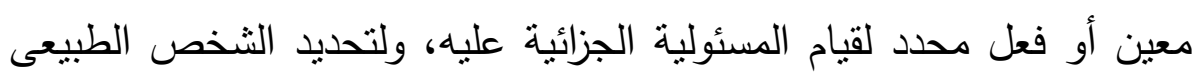

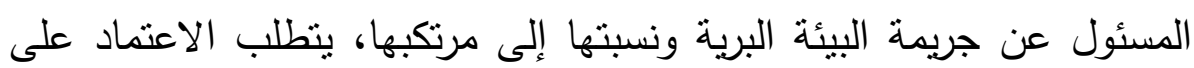
الإسناد القانونى، والإسناد المادى، والإنابة فى الاختصاص.

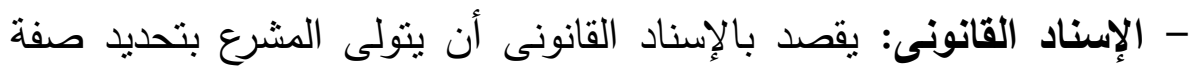

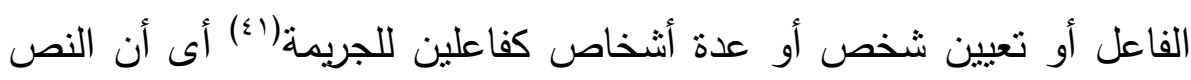

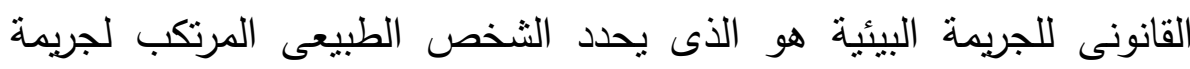
البيئة البرية، عن طريق الإشارة إليه بصفة صريحة أو ضمنية، فالإسناد الصريح يكون بتحديد الثخص المسئول عن الجريمة البيئة بالصفة والوظيفة الئهة

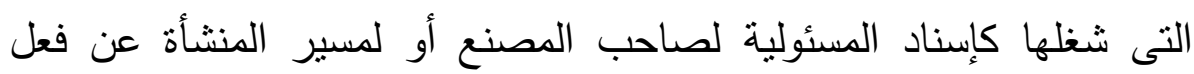
تلويث البيئية البرية الذى يحدثه أحد تابعيه متى كانوا خاضعين لرقابته وإنشرافه،

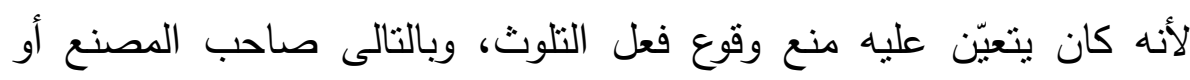

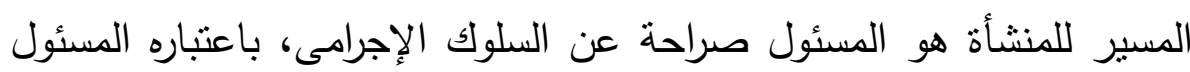

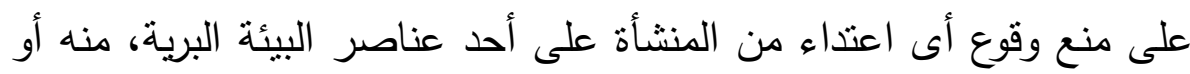

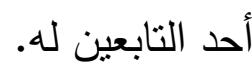

أما الإسناد الضمنى: فيه لا يحدد القانون صراحة الثخص المسئول عن

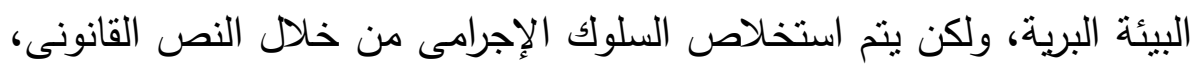

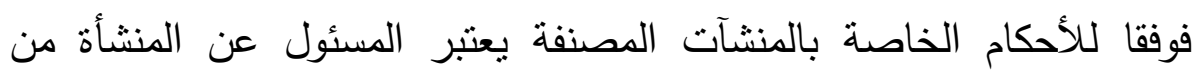

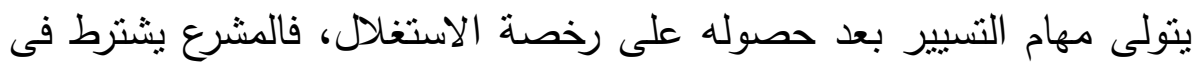
حالة تغيير مستغل المنشأة أن يقوم المستغل الجديد أو من ينويه بالتصريح

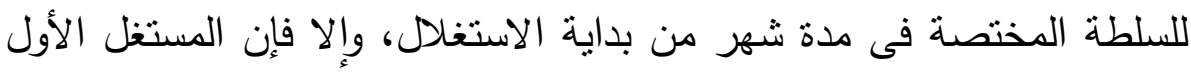


هو من يتحمل المسئولية الجزائية فى حالة حدوث تلويث للبيئة البرية أو

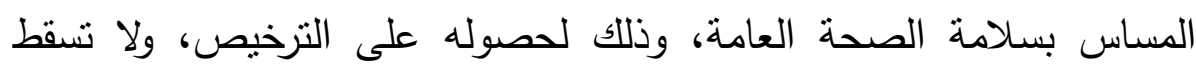

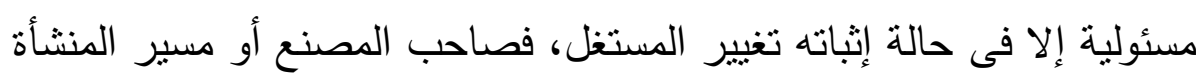

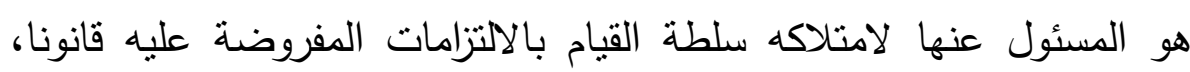

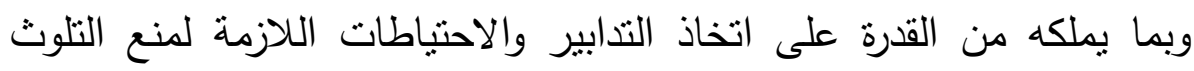

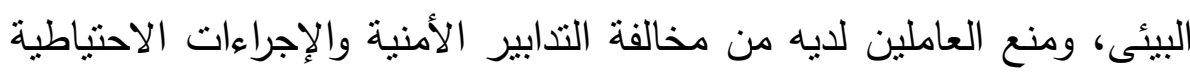
المقررة لمنع حدوث تلوث البيئة البرية.

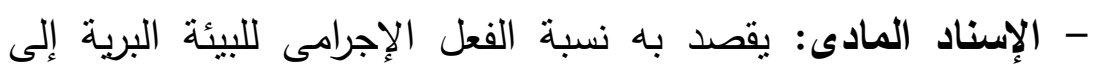

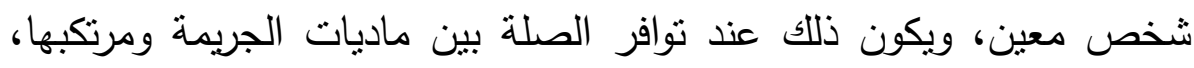

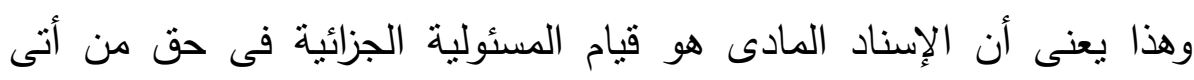

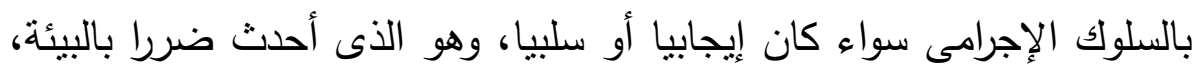

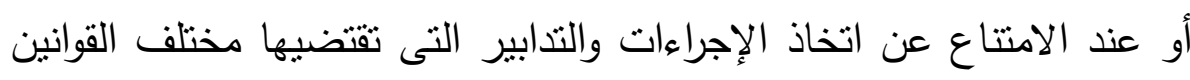

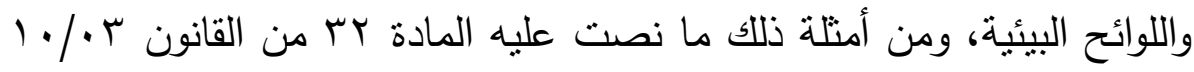

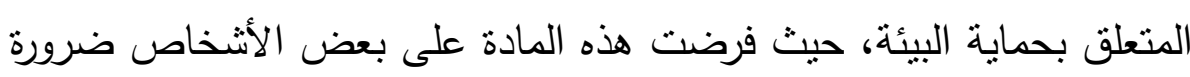

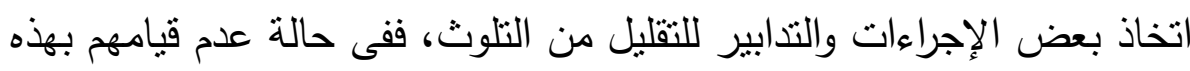
الإجراءات والتدابير يعتبرون مسئولين جنائيا بحكم هذا الإسناد المادى.

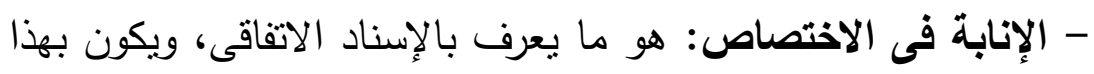

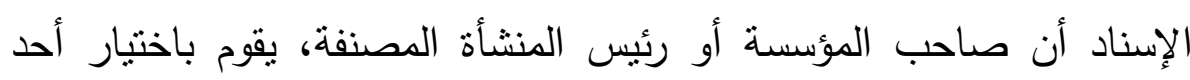

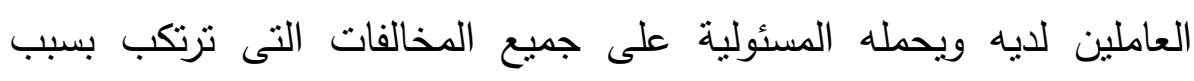

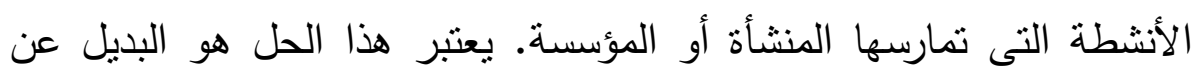
تقرير المسئولية الجزائية للثخص المعنوى. 
كما يعتبر هذا الإسناد الاتفاقى ذا أهمية بالغة فى حالة تداخل الاختصاصات داخل المؤسسة أو المنشأة، حيث يصعب تحديد علاقة السببية بين النتيجة الإجرامية ومرتكب السلوك الإجرامى الملوث للبيئة البرية. ب- هسئولية الشخص المعنوى عن الجرائم الماسة بالبيئة البرية

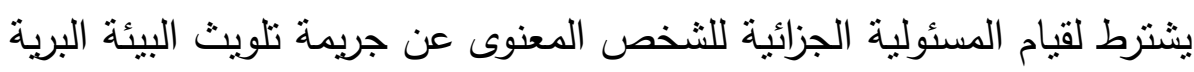

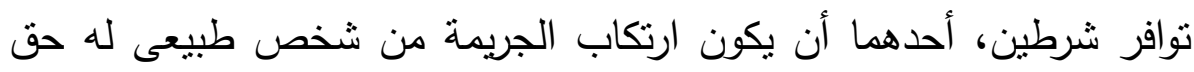

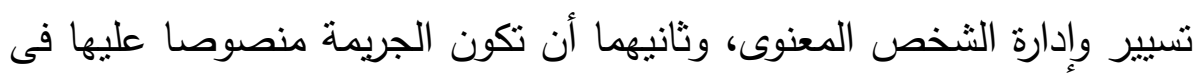

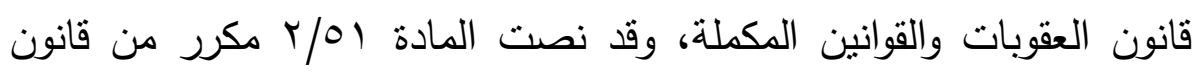
العقوبات الجزائرى بقولها : "... يكون الثخص المعنوى مسئولا جزائيا عن الهن الجرائم التى ترتكب لحسابه من طرف أجهزته أو ممنليه الثرعيين عندما ينص التصن

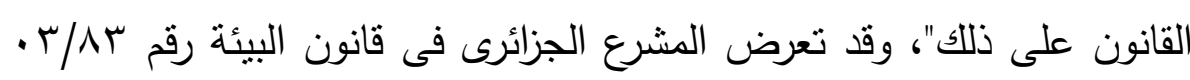

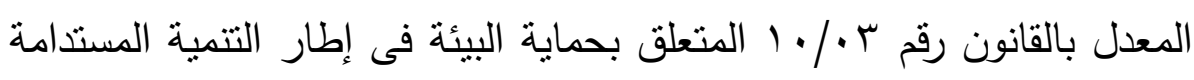

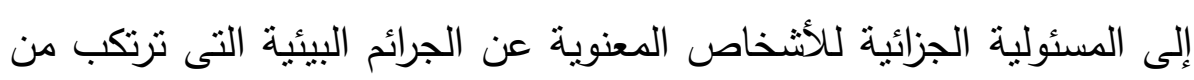

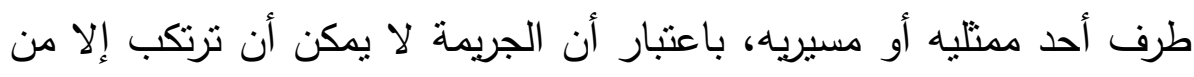

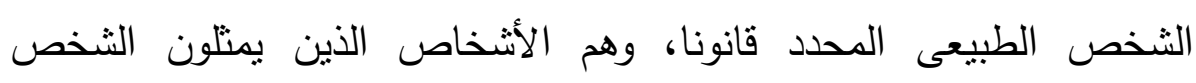

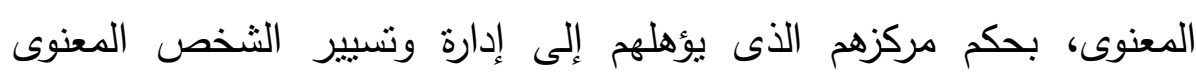
والإثراف عليه.

غير أن الثخص الطبيعى أو المعنوى بعفى من المسئولية الجزائية عن

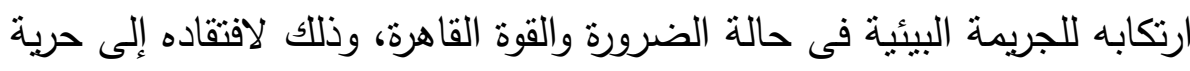

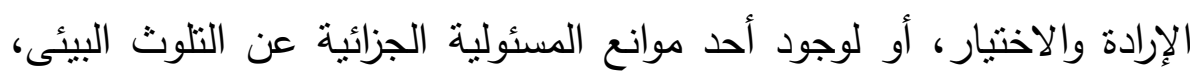

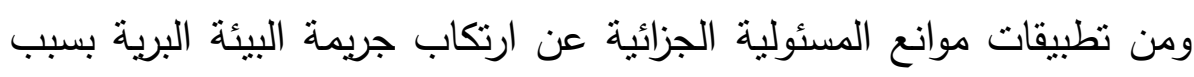
الحصول على النرخيص، أو إثبات بأنه لا يد له فى ارتكاب الجريمة البيئية. 


\section{r- العقوبات المقررة على الجرائم الماسة بالبيئة البرية}

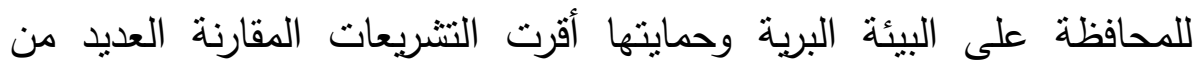
العقوبات لمواجهة المخالفات الماسة بالبيئة البرية، وجاءت قوانين العقوبات

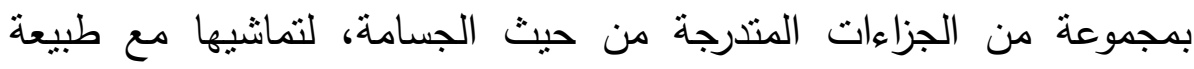

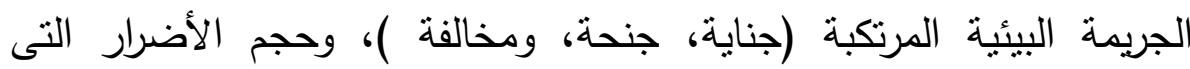

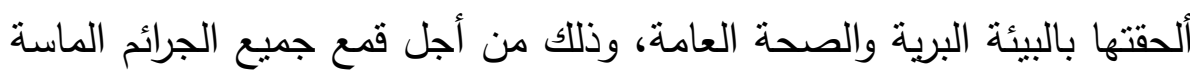

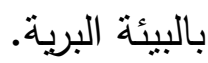

وهى العقوبات نفسها المطبقة على الجرائم العادية والمنصوص عليها فى المادة ه من قانون العقوبات الجزائرى بقولها: "العقوبات الأصلية فى مادة

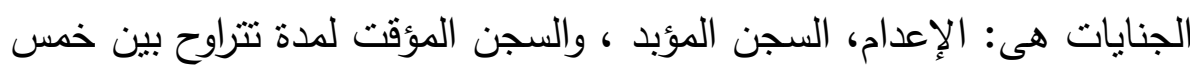

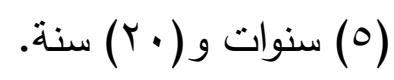

العقوبات الأصلية فى مادة الجنح هى: الحبس مدة تتجاوز شهرين إلى

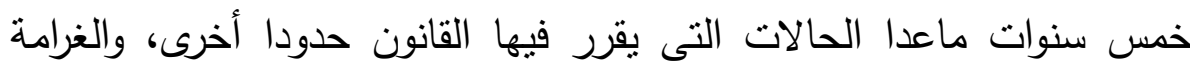

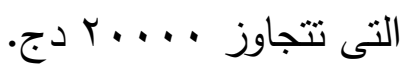

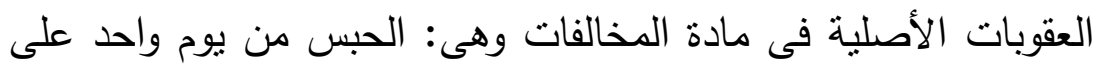

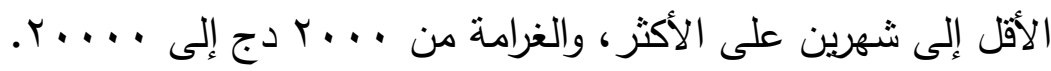

\section{أ- الجنايات الكاسة بالبيئة البرية وعقوباتها}

ومن العقوبات التى كرستها التشريعات المقارنة لجرائم البيئة البرية نذكر: - عقوية الإعدام على مرتكبى الجرائم الماسة بالبيئة البرية

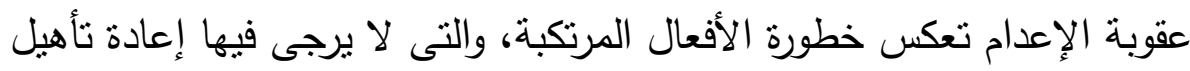

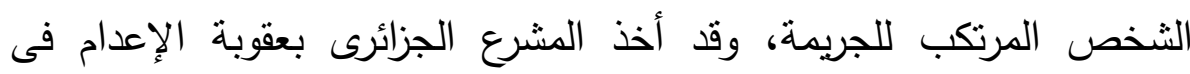


مكافحته لجرائم تلويث البيئة البرية والجرائم المهدة للصحة العامة، وهذا ما

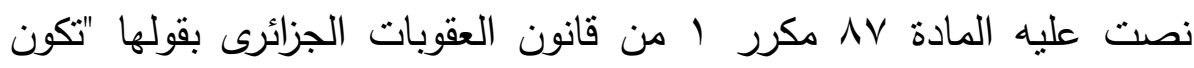

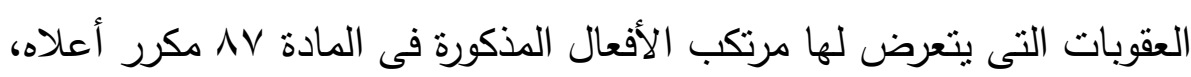
كما يأنى التوبات الإعدام عندما تكون العقوبة المنصوص عليها فى القانون السجن

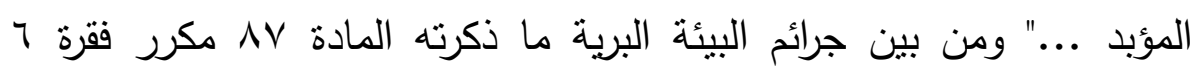

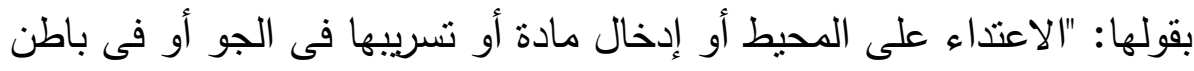

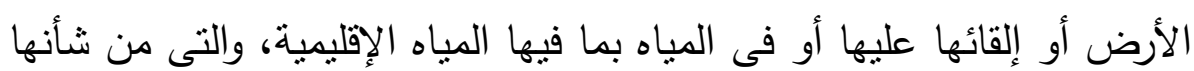

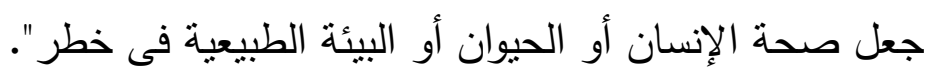

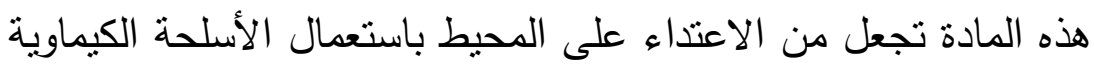

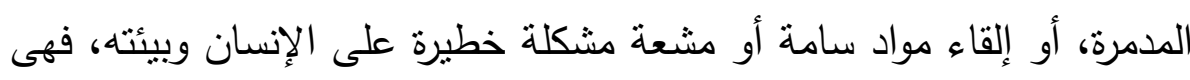

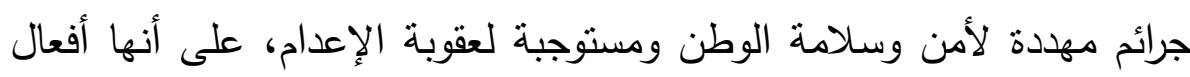

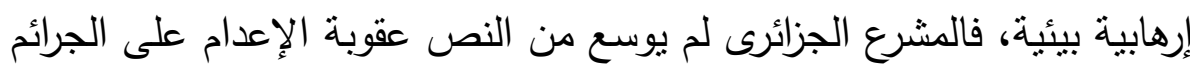
الماسة بالبيئة البرية، إلا ما ذكره فى المادتين السابقتين.

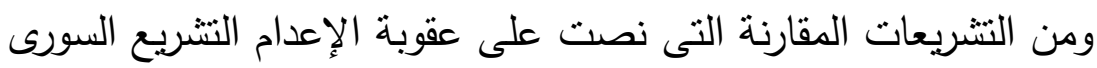

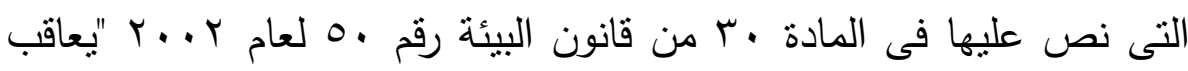

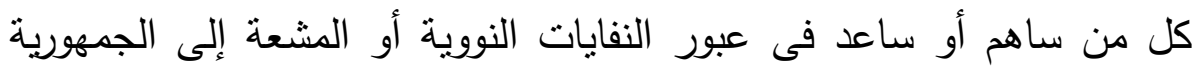

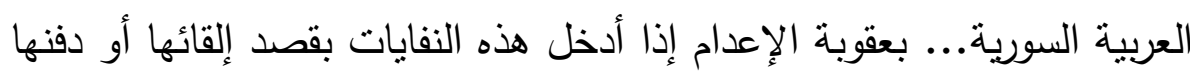
أو إغراقها أو إحراقها أو تخزينها فى الجمهورية العربية السورية". يتم إقرار عقوبة الإعدام لبعض الجرائم البيئية على أساس أن هذه الجرائم البيئية تهدد حياة الأفراد وتعرضهم للخطر والتنسبب فى كوارث بيئية. 
- عقوية السجن على مرتكبى الجرائم الماسة بالبيئة البرية وهى مقررة للجرائم الموصوفة بأنها جناية بيئية، وهى على على نوعين هما:

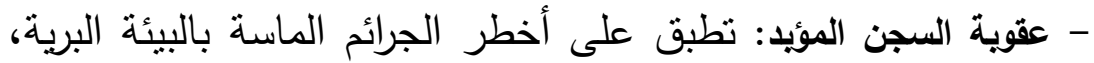

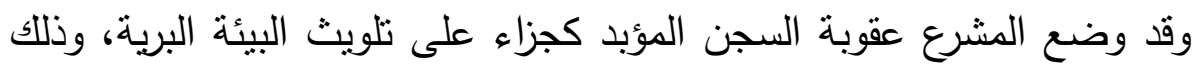

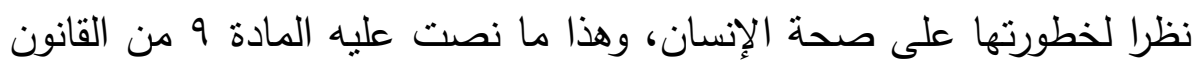

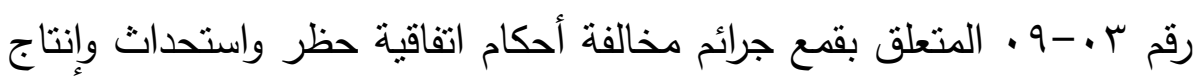
وتخزين واستعمال الأسلحة الكيماوية وتدمير تلك الأسلحة.

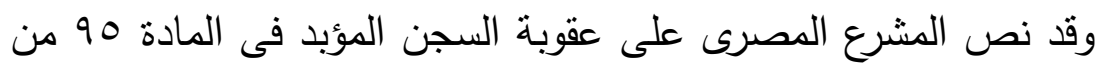

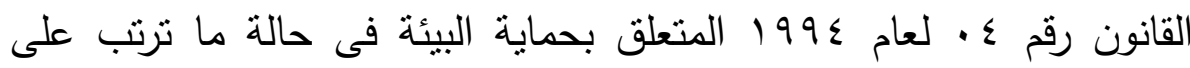
جريمة تلويث البيئة وفاة ثلاثة أثخاص فأكثر . وقد نص المشرع الجزائرى على هذه العقوبة فى المادة 9 ـ ا من القانون

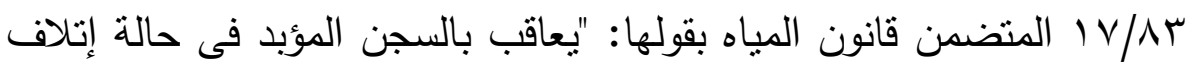

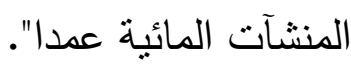

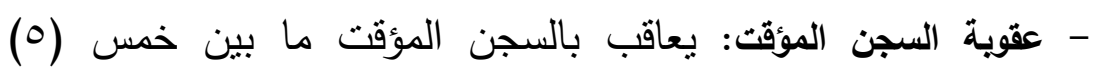

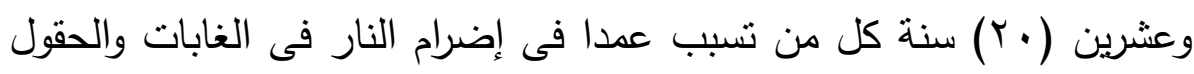

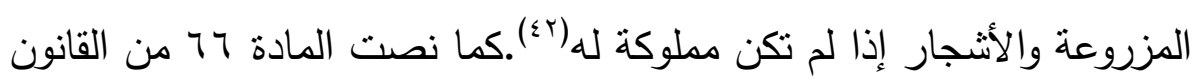

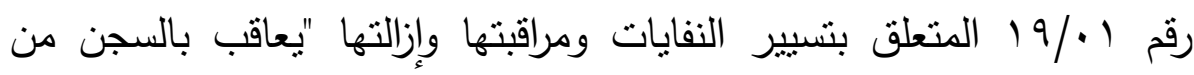

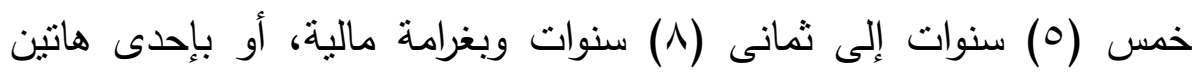

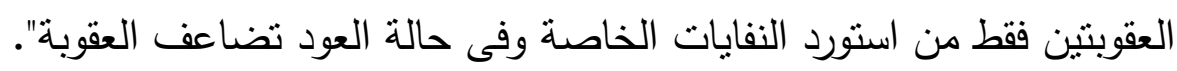

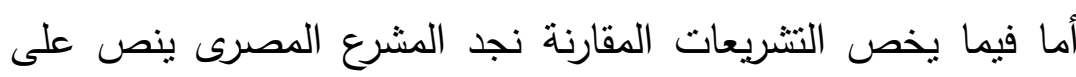
عقوبة السجن المشدد على مرتكبى جرائم المناجرة بالنفايات الششعة أو تسريبها

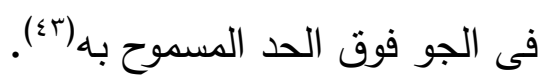


إن أغلب التشريعات المقارنة صنفت الجرائم الماسة بالبيئة على أنها جنح ومخالفات، وذللك وفقا لخطورتها الإجرامية.

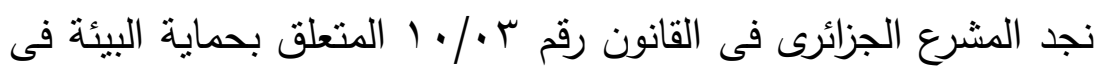

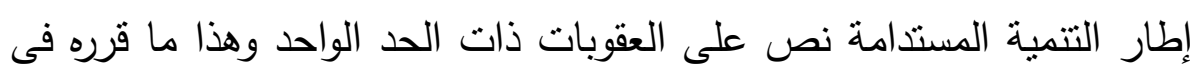
المادة r ب. بقوله "يعاقب بالحبس سنة واحدة وبغرامة كل من استغل منشأة

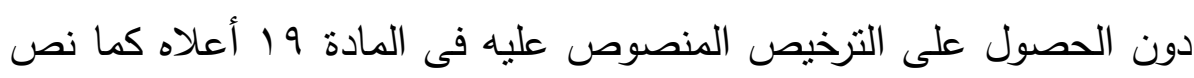

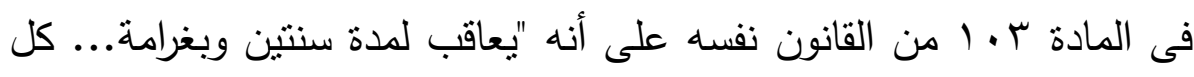

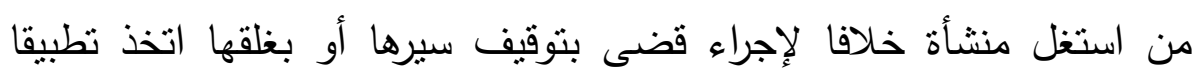

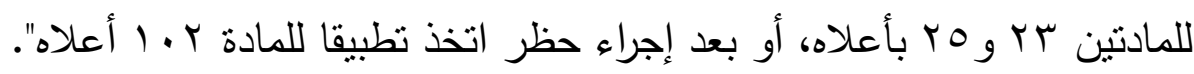

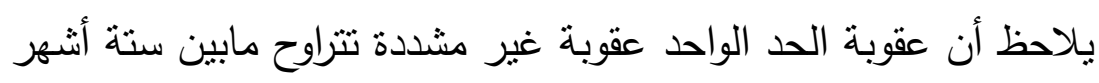

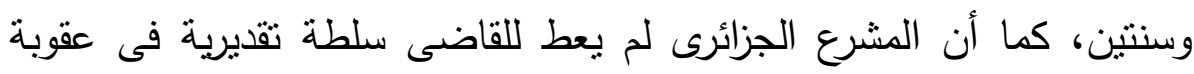

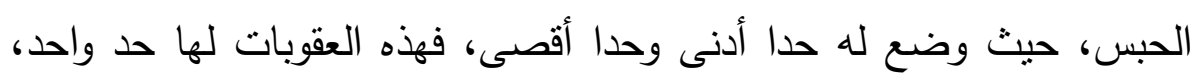
وبالتالى القاضى يطبق النص كما هو دون تفعيل لسلطته النقديرية.

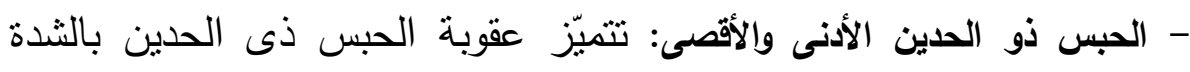

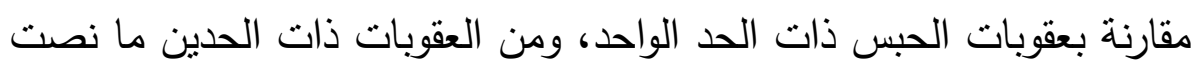

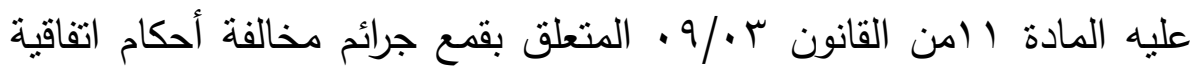

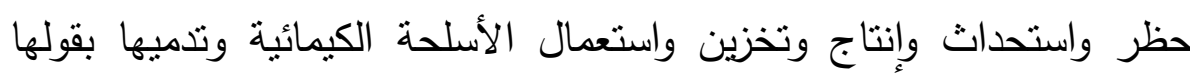

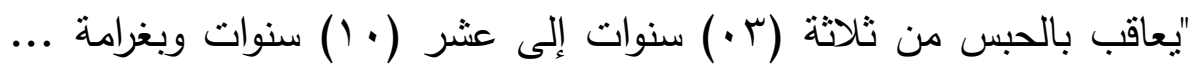
كل من ستورد أو يصدر أو يقوم بالعبور أو الاتجار أو السمسرة بمواد كيميائية

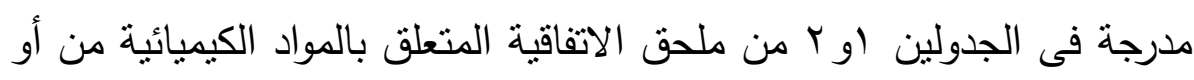
إلى دولة ليست طرفا فى الاتفاقية". 
كما نصت المادة ؟ + ا من القانون رقم 91-ــ ـ المتعلق بحماية التراث الثقافى على أنه "ينعرض كل من يصدّر بصورة غير قانونية ممنلكا ثقافيا

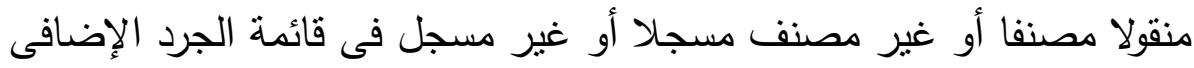

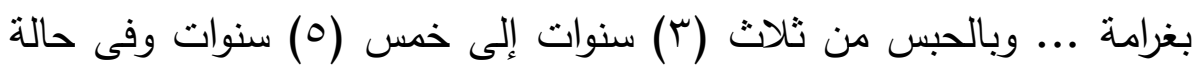

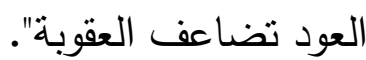

\section{والمالفات الماسة بالبيئة البرية وعقوباتها}

تعد المخالفات كثيرة فى المجال البيئى، فقد وردت هذه الجرائم فى العديد من

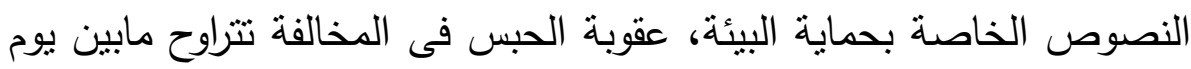

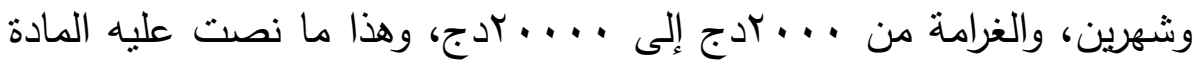

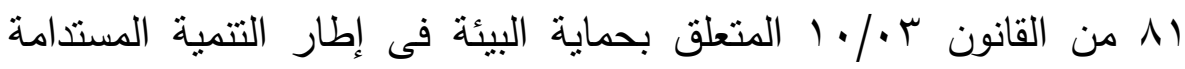

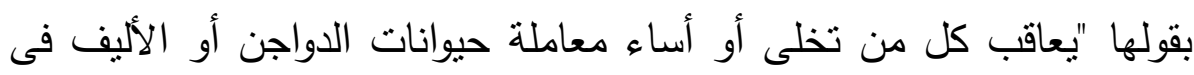

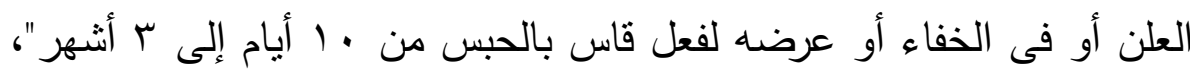

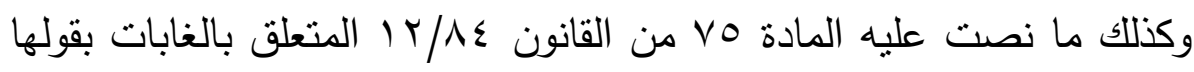
"بعاقب كل من أنشعل المنتجات الغابية أو نقلها من دون ترخيص بالحبس من العن

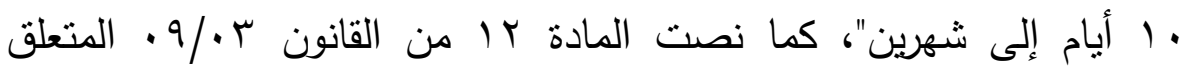

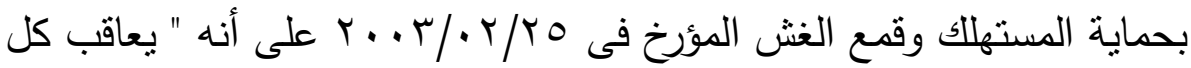

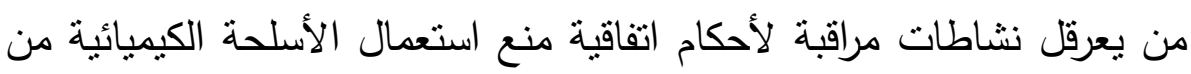

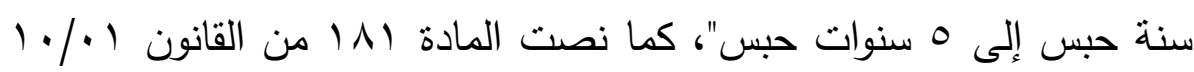

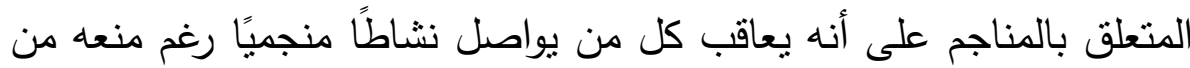

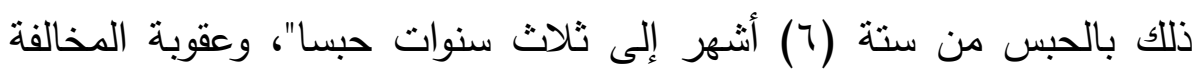
شبيهة بعقوبة الجنحة يمكن أن يكون لها حد واحد أو حدان، أما عقوبة الغرامة 
فهى من العقوبات الأصلية التى تمس الذمة المالية للمحكوم عليه والتى تؤول إلى الخزينة العمومية للاولة.

\section{r- العقوبات التكميلية والتدابير الاحترازية لجرائم البيئة البرية}

تعتبر العقوبات التكميلية هى عقوبات مكملة للعقوبات الأصلية، والتى لا يجوز

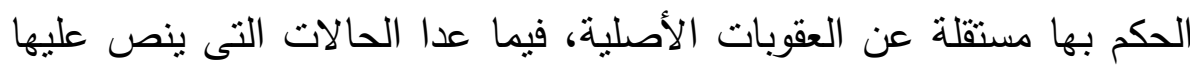

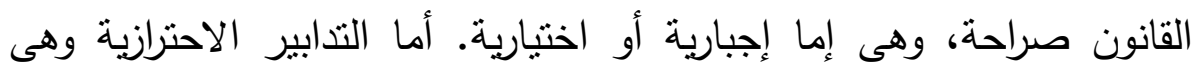

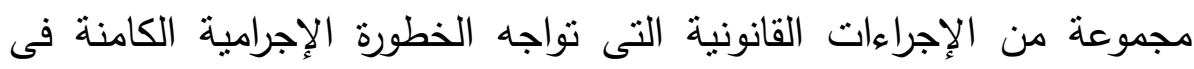

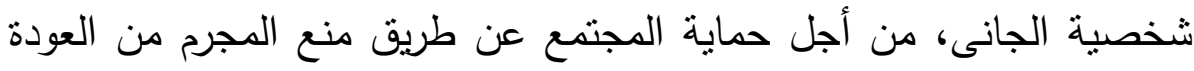

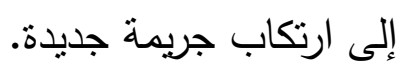

وقد أخضع المشرع الجزائرى جرائم البيئة البرية إلى العقوبات التكميلية

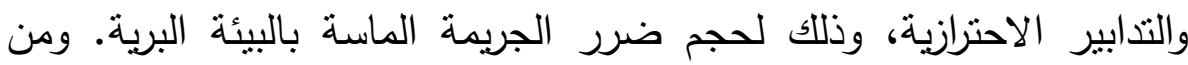
العقوبات التكميلية والتدابير الاحترازية التى نص عليها ودئها المشرع الجزائرى كجزاء مترتب عن جريمة البيئة البرية نذكر الآتى:

أ- عقوية المصادرة

تعتبر عقوبة المصادرة من العقوبات المالية، لأنها تجرد المحكوم عليه من

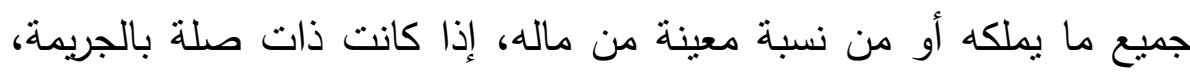

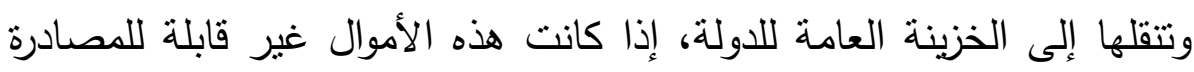

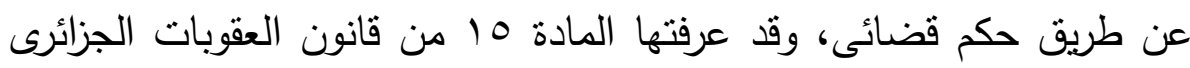

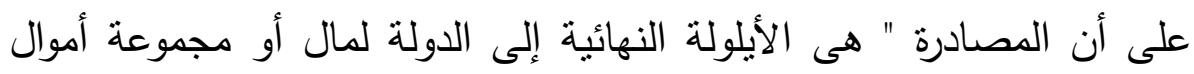

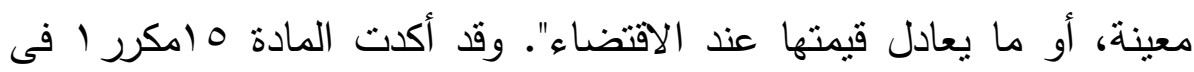
فقرتها على أنه "فى حالة الإدانة لارتكاب جنحة أو مخالفة يؤمر بمصادرة 
الأثياء المذكورة فى الفقرة السابقة وجوبا إذا كان القانون ينص صراحة على هذه العقوبة، وذللك مع مراعاة حقوق الغير حسن النية". وتكون المصادرة على نوعين وجوبية واختيارية، وتكون المصادرة الوجوبية فى الجرائم التى نأخذ وصف الجنايات، التى تتم فى جميع الحالات

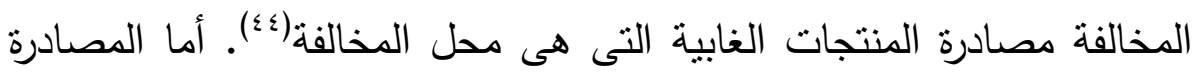

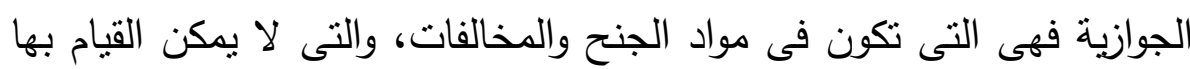

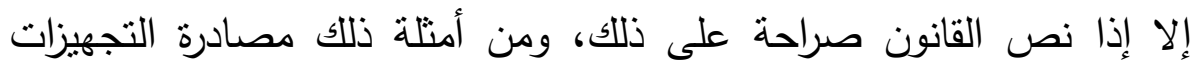
والمعدات التى استعلت فى إنجاز الآبار أو حفر جديد أو تغييرات بداخل مناطق الحماية الكمية للمباه(؛؛). وقد نص المشرع الجزائرى على عقوبة المصادرة-أيضا- فى قانون

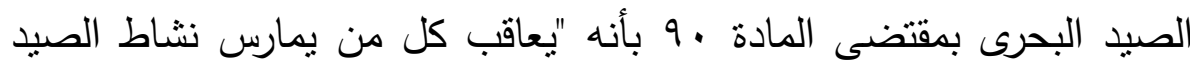
باستعمال الوسائل المنوعة...... وفى كل الحالات تتم مصادرة الوسائل

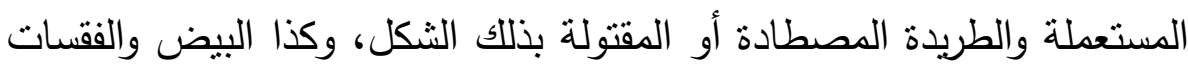

$$
\text { والحيوانات وصغارها"( (؟). }
$$

ويشترط لتطبيق عقوبة المصادرة ضد المحكوم عليه، أن تكون هذه

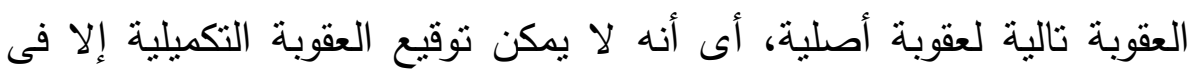

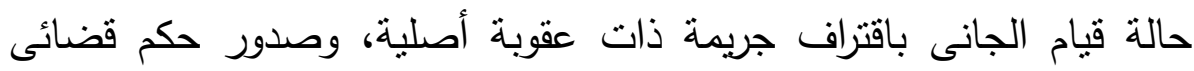

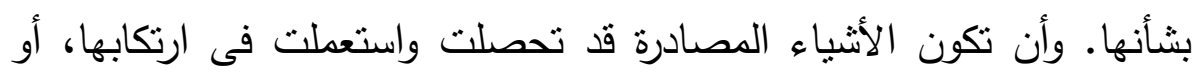
كانت معدة للاستعمال فيها، وأن تكون الأشياء المصادرة مضبوطة حادئ حال وأثناء

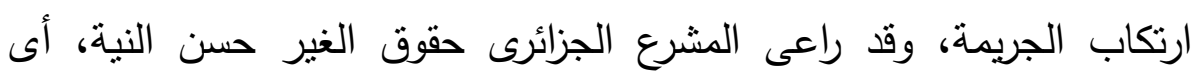

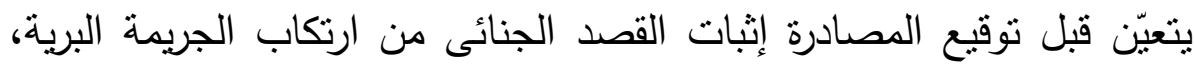


فإذا ثبت للقاضى انعدام القصد الجنائى للمتهم بارتكاب الجريمة، فإنه لا يوقع عليه عقوبة المصادرة.

ب- عقوية المنع المؤقت من ممارسة النشاطات ذات الصلة بالبيئة البرية

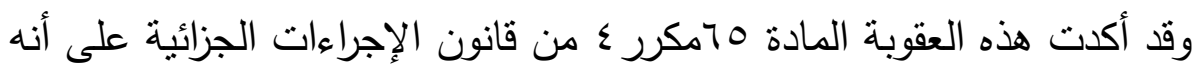

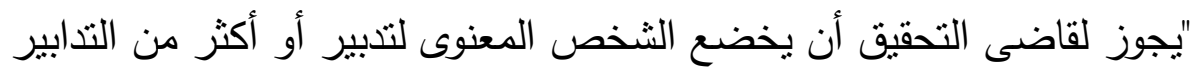

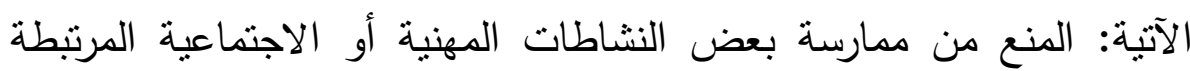

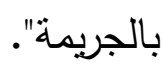

وقد جسد المشرع الجزائرى هذه العقوبة فى جرائم البيئة البرية فى المادة

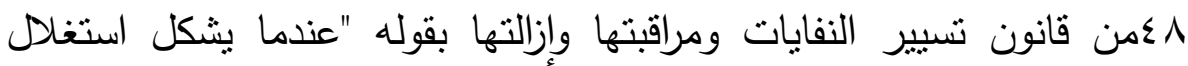

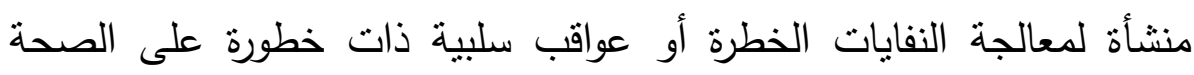

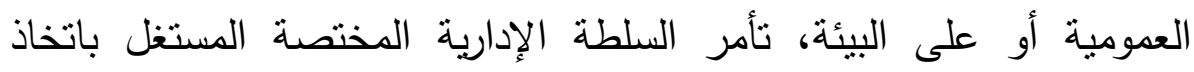
الإجراءات الضرورية فورا لإصلاح هذه الأوضاع، وفى حالة عدم امتثال المعنى بالأمر، تتخذ السلطة المذكورة تلقائيا الإجراءات التحفظية الضرواع، وفئ الضرورية على حساب المسئول، أو توقف كل النشاط المجرم أو جزءا منه".

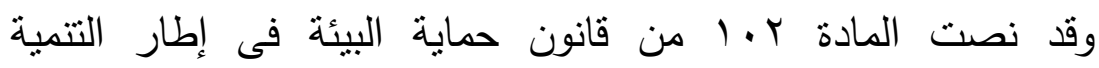

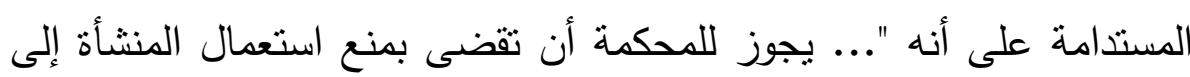
حين الحصول على الترخيص ضمن الثروط المنصوص عليها فى المادتين إنها

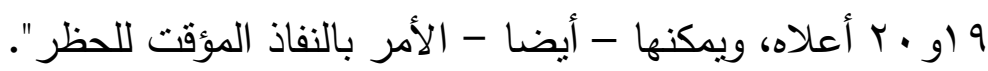

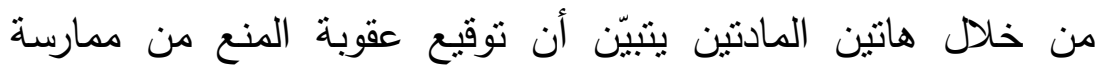

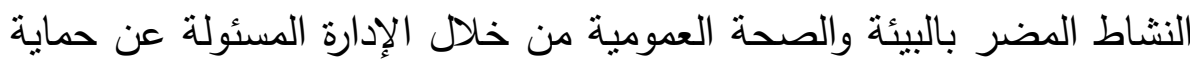

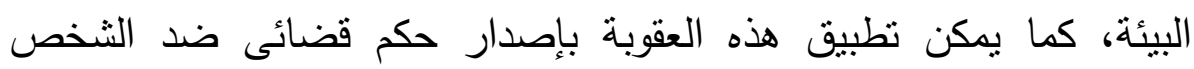
المخل بالتزاماته تجاه البيئة البرية. 
ج- نثر وتطليق الأحكام القضائية ذات النشاط المحظور بالبيئة البرية

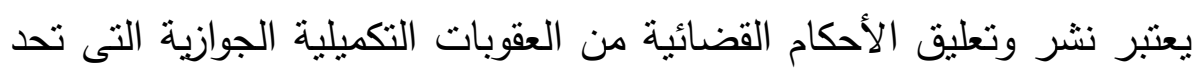

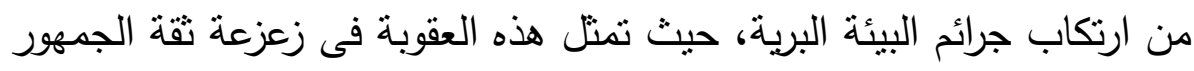

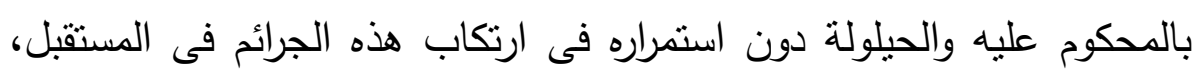

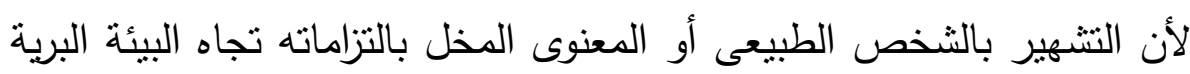
يكون أثند من العقوبات الأصلية التى تتفذ فى الخفاء ومن إطلاع الجمهور عليها.

وهذا ما أخذ به المشرع الجزائرى فى المادة ل1 المن قانون العقوبات

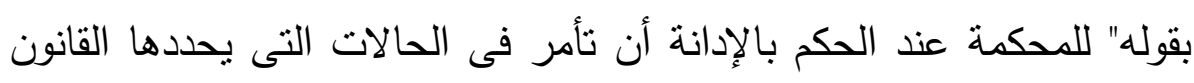

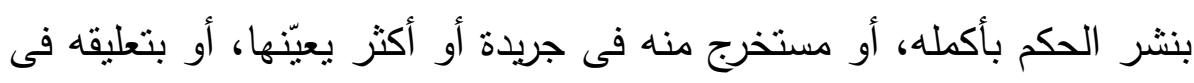
الأماكن التى يبينها، وذلك كله على نفقة المحكوم عليه، على ألا تنجاوز

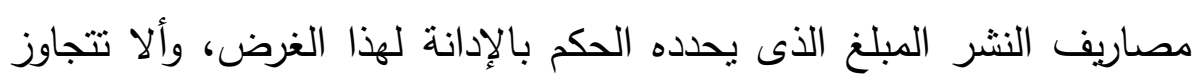

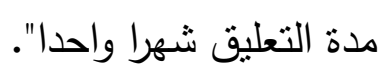

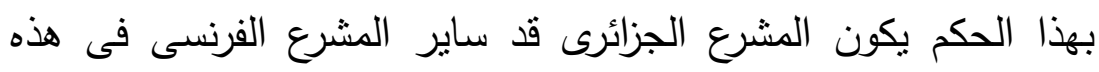

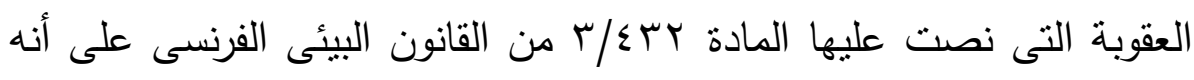

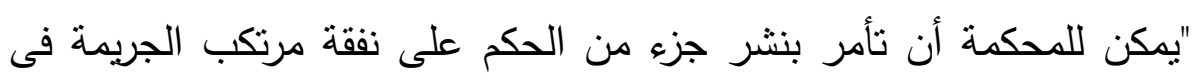
جريدتين تقوم المحكمة بتعبينهما".

د - غلق المؤسسة أو المنثأة المنتهكة للبيئة البرية أو أحد فروعها

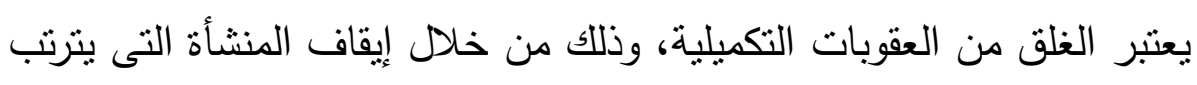

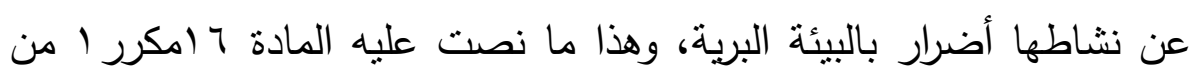

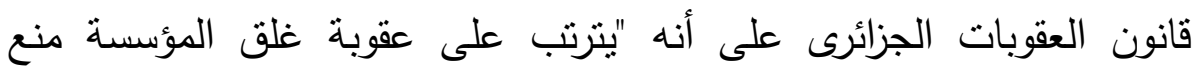


المحكوم عليه من أن يمارس فيها النشاط الذى ارتكبت الجريمة بمناسبته،

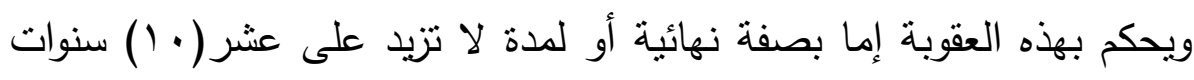

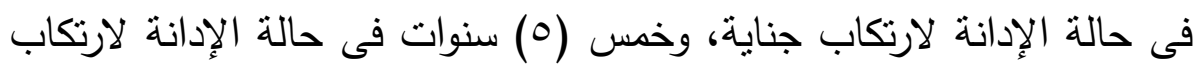
جنحة، ويجوز أن يؤمر بالنفاذ المعجل بالنسبة لهذا الإجراء".

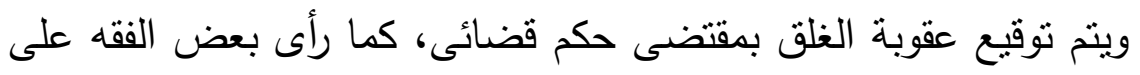

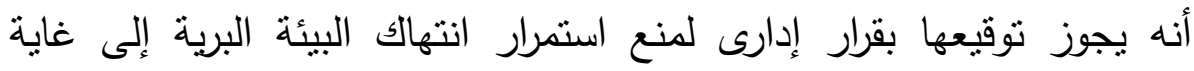

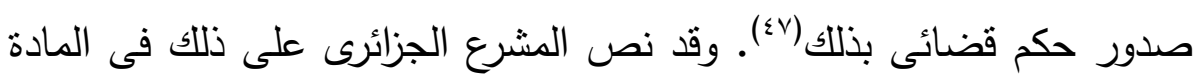

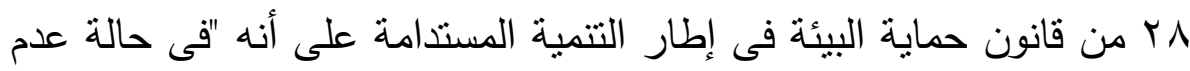

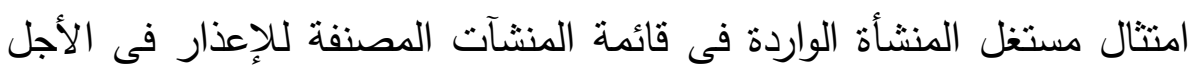
المحدد يوقف سير المنشأة إلى حين اتخاذ الثروط المفروضة".

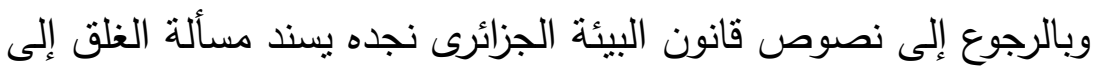

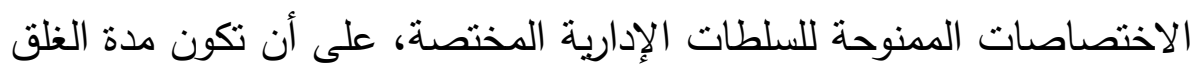
محدة فى القرار الإدارى الصادر بالغلق، ونظام الغلق يكون لفترة زمنية

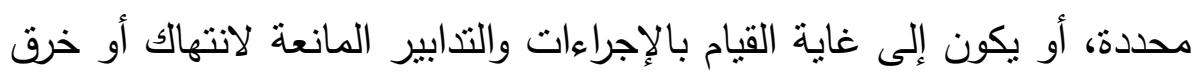

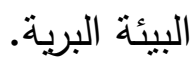

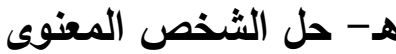
وتهدف هذه العقوبة إلى وقف استمرار المنشأة المصنفة من مخالفة أحكام

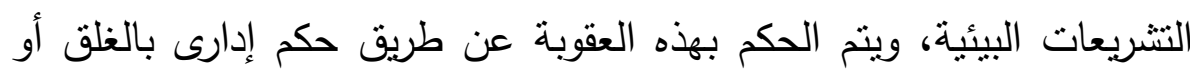

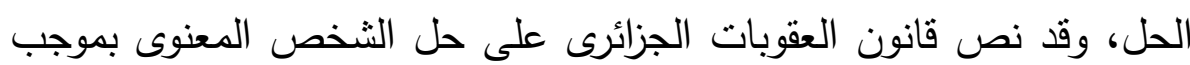

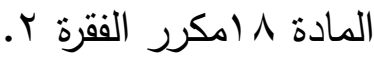




\section{الخاتمهـة}

إن القانون الجنائى البيئى جاء لحماية البيئة من حالات الاعتداء عليها، وذللك من خلال قمع كل الأفعال التى ترتكب فعلا على البيئة بأنواعها المختلفة البربة والجوية والبحرية، والتى ينتج عنها تهديد لكيان المجتمع وسلامة أفراده. إنّ تقرير الحماية الجنائية للبيئة وجعلها موضع التنفيذ الفعلى، لا يتوقف فقط على وجود الضرر وإثباته من خلال تقديم شكوى أو إجراء معاينة على محضر أو الإبلاغ عنه، بل بتطلب قيام الجهة المكلفة قانونا بأعمال المتابعة من جهة، وتحريك الدعوى العمومية ومباشرتها من جهة أخرى.

وتماشيا مع مبدأ الشرعية الجنائية جاءت النصوص الحامية للبيئة فى القانون

الجزائرى مبعثرة بين نصوص القانون والقانون الخاص، كما جاءت نصوصها كاشفة للجزاءات التى قررها المشرع لمواجهة حالات انتهاك أحكام وقواعد القانون البيئى، وبالخصوص حالات الاعتداء على مكونات وعناصر البيئة، وقد جاءت العقوبات البيئية متأرجحة بين الثدة والتخفيف، فالمشرع الجزائرى متشدد فى جريمة إدخال مواد

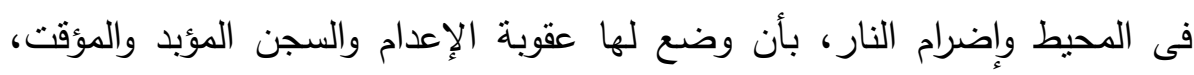

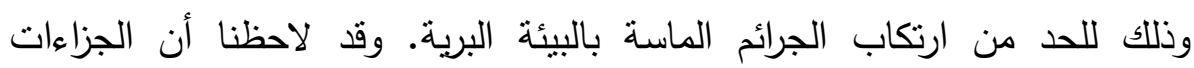
المنصوص عليها فى قوانين حماية البيئة جاءت متدرجة فى الثدة، ونتراوح عقوباتها بين الحبس والغرامة. كما نصت كل التشريعات المقارنة على العقوبات التكميلية والتذابير الاحترازية على مرتكبى بعض الجرائم البيئية، كما أدرج فى كثير من قوانين حماية البيئة بعض الئل العقوبات الإدارية، والتى تكون عادة سابقة على الجزاءات الأصلية والتكميلية، كإعذار مرتكب الجريمة البيئية على العدول عن فعله الإجرامى والالتزام بالتتظيم المعمول به، وفى حالة عدم الامتثال للإعذار المقدم له، يتعرض إلى تطبيق العقوبة الإدارية عليه، ومن أمتلة ذلك عقوبة سحب قرار الترخيص بمزاولة النشاط المترتب عليه إضرار بالبيئة أيًا كانت طبيعتها. 
فى الاقتراحات النى نساهم بها فى إطار الحافظة على البيئة البرية وحمايتها

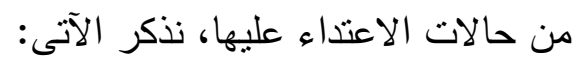

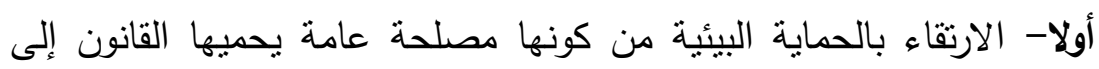
كونها حقًا من حقوق المواطنة، يتطلب من الدولة تكريسها دستوريا وفعليا، فى بيئة سليمة وصحية ونظيفة.

ثانيا- مراجعة تتظيم نصوص البيئة عن طريق جمعها فى مدونة قانونية شاملة حتى يسهل الرجوع إليها، لمعرفة كل ما ينعلق بها من أحكام وتدابير وإجراءات، وجزاءات عقابية وإدارية.

ثالثا- استحداث هيئة أمنية لحماية البيئة وجعلها مستقلة عن شرطة العمران،

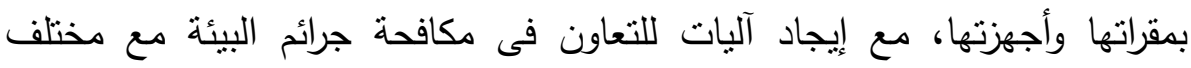
الأجهزة الأمنية كالشرطة والدرك والجيش، وأجهزة القضاء العادى والإدارى. لإنات

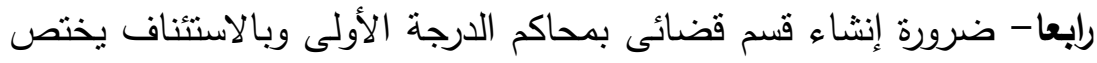

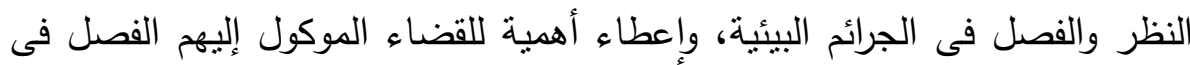

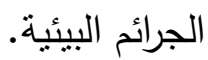
خامسا- وضع سياسة جنائية متكاملة لمكافحة خطر التلوث البيئى والحد من

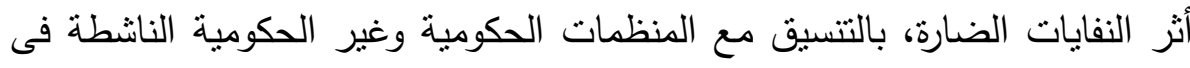
مجال الحد من الأضرار البيئية. سادسا - تثجيع الدول على التصديق على المواثيق والصكوك الدولية الحامية

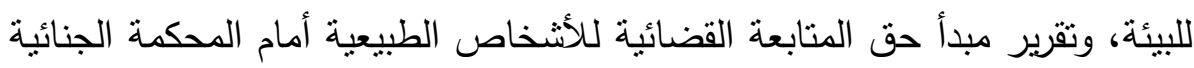

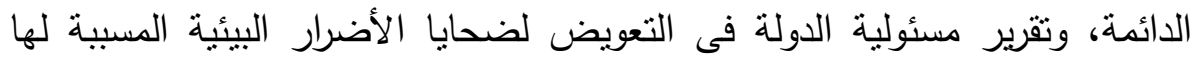
بانتهاكها لأحكام وقواعد القانون البيئى. 